Portland State University

PDXScholar

Winter 3-28-2019

\title{
"The Most Difficult Vote": Post-Roe Abortion Politics in Oregon, 1973-2001
}

Tanya Trangia Monthey

Portland State University

Follow this and additional works at: https://pdxscholar.library.pdx.edu/open_access_etds

Part of the History Commons, and the Women's Studies Commons Let us know how access to this document benefits you.

\section{Recommended Citation}

Monthey, Tanya Trangia, "'The Most Difficult Vote": Post-Roe Abortion Politics in Oregon, 1973-2001" (2019). Dissertations and Theses. Paper 4822.

https://doi.org/10.15760/etd.6698

This Thesis is brought to you for free and open access. It has been accepted for inclusion in Dissertations and Theses by an authorized administrator of PDXScholar. Please contact us if we can make this document more accessible: pdxscholar@pdx.edu. 
"The most difficult vote"

Post-Roe Abortion Politics in Oregon: 1973-2001

by

Tanya Trangia Monthey

A thesis submitted in partial fulfillment of the requirements for the degree of

Master of Arts

in

History

Thesis Committee:

Marc Rodriguez, Chair

Patricia Schechter

Katrine Barber

Chris Shortell

Portland State University

2019 


\begin{abstract}
$\underline{\text { Abstract }}$
The abortion debate in the United States has come to split the contemporary electorate among party lines. Since the late 1970s, the Republican Party has taken a stand against abortion and has worked through various routes of legislation to pass restrictions on access to the procedure. Oregon however, provides a different interpretation of this partisan debate. Though Oregon has seen both Republican and Democratic leadership in all houses of state government and pro-life conservative groups have lobbied to restrict the procedure, no abortion restriction has been passed in the state since the United States Supreme Court invalidated many state abortion bans in 1973.

This thesis analyzes the legislative history of Oregon beginning in the mid nineteenth century, when the Oregon Territory first passed an abortion ban. Oregon voters and lawmakers alike were continuously asked to debate the legality and morality of abortion. Though the state did participate in the national debate over access to abortion, made clear by dozens of attempts at restricting the procedure, Oregon's response to conservative political trends is distinctive.

Oregon liberalized its abortion law before Roe was decided; and years before, prominent physicians provided abortions and advocated for reproductive health. After abortion was decriminalized, Oregon legislators protected abortion access further by rejecting all attempts to pass abortion restrictions and crafting legislation to make further restrictions more difficult to pass. Even as Republicans gained majorities in the Oregon legislature in the late 1980s and 1990s and the pro-life movement gained momentum on the statewide level nationally, Republican lawmakers remained unwilling to prioritize abortion legislation. So too, in the decades following the Roe decision, Oregon voters
\end{abstract}


have rejected all pro-life attempts to restrict abortion access by ballot initiative. Instead of pointing to one explanation for Oregon's protection of abortion access, this thesis examines the societal and legislative developments that worked in tandem to create a legislative landscape that is protective of abortion. 


\section{Acknowledgements}

At times I questioned not only my ability to finish this thesis, but even my own desire to do so. If it was not for the support system I have built of family and friends during this time, I would not have been able to finish this project. I thus owe a great debt of gratitude to my fellow history department graduate students whose writing sessions provided me with much needed writing time. Will Schneider, Lyndsay Smith, Taylor Bailey, Greta Smith, and Alex Ritter encouraged countless hours of research and writing.

Writing a thesis while working full time would not have been possible without Nicole Kindle, who met me every weekend for our writing dates. I would not have been able to finish without your accountability. Also thank you to Jenna Barganski and Katie Nelson for the dinner and writing nights. I benefitted from any excuse to get together with good friends to chat and write a little.

I have had incredible guidance while at Portland State. Thank you to Katrine Barber, for sparking my interest in Oregon abortion politics. Entering the program I knew I wanted to focus on birth control in the United States, but your expertise in Oregon history pointed me in this direction and I cannot explain how thankful I am for your help. I also owe so much thanks to Professor Barber for spending so much time helping me with the writing and editing process.

Thank you to Patricia Schechter, who really pushed me to expand the scope of my research throughout my studies. Our meetings challenged me more than I expected, but I am a better scholar for it. Catherine McNeur, David Johnson, David Del Mar, Jennifer Kerns, Chris Shortell all helped me a great deal during my time at PSU and their insight and criticism has made me a better writer. To my friends and coworkers Kali Mustafa, 
and Jess Moore, thank you for taking the time to read my thesis and offer me edits. Writing is not my strong suit and everyone's suggestions really made my paper more palatable. Thank you to my thesis advisor Marc Rodriguez. You really pushed me to graduate and your criticism shaped my work. This project was made possible by your mentorship.

I also wish to sincerely thank the researchers and staff at the Oregon State Archives, Portland State University Special Collections, Oregon Historical Society's Davies Research Library and OHSU. I did not find all of these collections on my own. I am incredibly lucky to have met wonderful archivists who know their collections and would bring me endless boxes that were ultimately crucial for framing my argument. At the end of the day, this thesis is not mine; it is entirely for my incredible parents. Your support has enabled me to both pursue this degree but reaffirmed my decision every step of the way. I am forever grateful for your influence. I love you, and thank you. 


\section{Table of Contents}

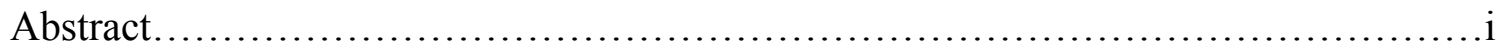

Acknowledgements.........................................................

List of Tables..................................................................

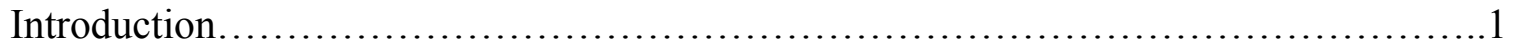

Chapter One

Pre-Roe Abortion History in Oregon; 1854-1973..................................10

Chapter Two

Establishing an Infrastructure for Reproductive Freedom:

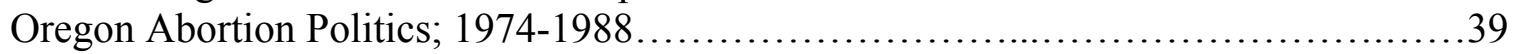

Chapter Three

"Nothing in the Constitution requires States to enter or remain in the business of performing abortions."

The Ideological Shift of the Court and State Abortion Politics; 1989-1992..............65

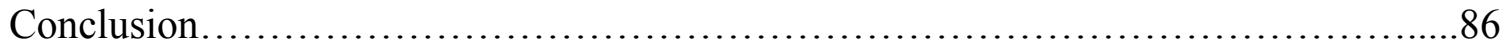

Bibliography........................................................... 89 


\section{List of Tables}

Figure 1. Oregon's Abortion Measures in relation to Supreme Court Decisions and Federal Legislation (47)

Figure 2. Introduced State Abortion Legislation (54-56)

Figure 3. Index for Ballot Measure Initiatives in Oregon Elections (72) 


\section{Introduction}

Vice President Mike Pence became the highest-ranking government official to attend the annual March for Life on January $27,2017 .{ }^{1}$ On that chilly morning in Washington D.C., Pence announced to a cheering crowd "life is winning again in America." Thus making it clear that President Donald Trump would ignore the nominee of President Barack Obama and appoint his own nominee to the United States Supreme Court to fill the seat left vacant for over a year following the death of Justice Antonin Scalia. ${ }^{2}$ Prior to Pence's attendance, the highest-ranking government official to speak at a March for Life was President Ronald Reagan who phoned in but did not attend the 1988 rally. Both Reagan and Pence incited the crowd with a promise to end "taxpayer funded abortions." ${ }^{3}$ Yet in fact, federal tax dollars are banned from such use. The Hyde Amendment of 1977 bans federal dollars from funding abortions. Widespread state legislation in the years since the Roe v. Wade decision also target funding, and have worked to construct a political landscape where access to abortion depends on geography

\footnotetext{
${ }^{1}$ The annual March for Life is a protest organized by religiously motivated advocates calling for the banning of all abortion procedures held on or around the anniversary of the 1973 Supreme Court decision Roe v. Wade.

${ }^{2}$ Mike Pence, Speech for Annual March for Life, January 27, 2017.

${ }^{3}$ For Ronald Reagan speech see "Remarks to Participants in the March for Life Rally January 22, 1988 " University of California Santa Barbara, The American Presidency Project: http://www.presidency.ucsb.edu.

${ }^{4}$ My research focuses specifically within the time period of 1973-2001 where fifty-four restrictive bills were introduced. The most popular legislative bills sponsored were regarding parental notification or the prohibition of state funding being used for the piblikeduPence, Speech for Annual March for Life, January 27, 2017. ${ }^{3}$ For RhenalldeRofagamespineenbssed rRemarks to Participants in the March for Life Rallyg to January 22, 1988 " University of California Santa Barbara, The American Presidency Project: http://www.presidency.ucsb.edu.
} 
and class. Though Roe legalized abortion in the United States, the years since are peppered with impassioned debate.

Roe is not the first time women's access to abortion was tested. Until the midnineteenth century, no state laws mentioned abortion. This changed when the newly formed American Medical Association (AMA) lobbied state legislatures until each state had an abortion ban. The second debate over abortion rights occurred in the second half of the twentieth century. Pro-life conservatives empowered by the Republican Party, worked in state legislatures to pass restrictive abortion laws.

While a handful of traditionally liberal states have resisted this conservative tide, Oregon in particular has a long-standing history of protecting reproductive rights. Moreover, Republican legislators in Oregon have not held consistent views regarding abortion restriction. While the Republican Party nationally has taken the pro-life stance in the abortion debate, Oregon Republicans have not chimed in. Through legislative and voter referenda, pro-life conservatives have failed to pass abortion restrictions in the state of Oregon after Roe legalized the procedure in $1973 .^{4}$

Until now, no comprehensive analysis exists of these failed attempts to restrict abortion rights in Oregon. This failure was not merely a result of pro-choice legislators and a pro-choice consensus among Oregon's people, but also skepticism on the part of state Republicans towards restrictive abortion legislation. ${ }^{5}$ As the pro-life movement in

\footnotetext{
${ }^{4}$ My research focuses specifically within the time period of 1973-2001 where fifty-four restrictive bills were introduced. The most popular legislative bills sponsored were regarding parental notification or the prohibition of state funding being used for the procedure.

${ }^{5}$ For the sake of cohesiveness, I refer regularly to "pro-choice" activist when referring to individuals in support of legal abortion. Conversely, "pro-life" individuals are those in
} 
Oregon sought to rewrite state law to mirror those in more pro-life states, both Oregon's legislature and citizens consistently rejected these efforts. I argue that not only is the late twentieth century a continuation of women's activism that Oregon has been so familiar with, but this consistent and well-organized activism on the local level and in the state legislature is to credit for the state remaining free from restrictions.

Though I outline Oregon's abortion history before the Supreme Court heard the arguments in Roe, my work focuses on the 1980s and 1990s - after the Women's Liberation Movement incorporated safe and legal abortion to their policy agenda. To explain the unique political landscape of both grassroots activism and legislative agendas concerning access to abortion in the United States, I draw upon histories of the birth control movement, women's liberation and activism, conservatism, and American legal history.

Women have always sought to control their own reproduction, including employing abortive techniques. In the progressive era of the early twentieth century the Catholic Church became increasingly concerned with abortion. ${ }^{6}$ Opposing abortion, as with opposing contraception, is part of the larger Catholic ideology which respects life at all stages and feels interruptions to the progression of life goes against natural law. This belief system has remained consistent across all policy that ends human life such as

favor of outlawing abortion or overturning Roe v. Wade. I understand that these binary terms are not all encompassing and more nuanced descriptors for those involved in the abortion debate are available, however this terminology is regularly self employed by each of the above mentioned groups and I shall refer to them as they would typically describe themselves.

${ }^{6}$ Daniel K. Williams, Defenders of the Unborn: The Pro-life Movement before Roe v. Wade, (New York, NY: Oxford University Press, 2016), 4, accessed December 5, 2018, Oxford Scholarship Online. 
euthanasia and capital punishment. Just as Catholics supported New Deal progressive policy of social improvement and welfare reform, they expanded this view to include protecting the unborn. ${ }^{7}$

Furthermore, access to birth control challenges traditional notions of gender, family, and society. Historically social and religious norms used childbirth and motherhood as a tool of control over women. ${ }^{8}$ By controlling women's reproduction, a patriarchal society is able to control women's opportunities and livelihoods. As described by early birth control advocates, the first part of women's full emancipation depends on a

\footnotetext{
${ }^{7}$ Williams, Defenders of the Unborn, 9. Williams provides a revisionist examination of the political movement in opposition to abortion. While many prominent abortion and birth control historians have traced the origins of the organized and mobilized pro-life movement to the opposition of women's liberation in the 1970s, Williams asserts that the origins actually are much earlier, with roots in 1930s social reform. I don't necessarily see these two interpretations of the pro-life movement as contradictory. While Williams provides convincing evidence to establish the origins of the pro-life movement within New Deal liberalism, the successes of abortion advocates in the mid to late twentieth century, and the re emergence of pro-life advocacy in the 1970s demonstrates that while the movement has been present for most of the twentieth century, its political power did not fully emerge until pro-lifers aligned themselves with socially conservative Republicans and posited the movement as a alternative to feminism.

${ }^{8}$ Linda Gordan, Woman's Bodies Woman's Right: Birth Control in America (New York: Penguin Books, 1974), 4. Rickie Solinger further examines historical systems of control carried out through legislating sex and reproduction in, Pregnancy and Power: A Short History of Reproductive Politics in America, (New York: New York University Press, 2005). Solinger focuses her research on the power structures inherent in pregnancy, childbirth, and motherhood. She argues that this power structure is visible throughout the existence of the United States and has affected women differently depending on their age, class, and race. ${ }^{8}$ She orients reproductive policy in American history by examining how and why laws, public policies, and community attitudes about sex and pregnancy have changed over time. She analyzes how such policies and attitudes have shaped the lives of various groups of women differently. Starting with the founding of the United States, Solinger outlines women's "reproductive capacity" as an inherent thread within broader national politics surrounding racializing people into particular groups and promoting white supremacy. Conversely, laws criminalizing miscegenation through interracial sex and marriage served to control white women's sexuality by determining whom she could have relations with and ultimately, what types of babies were to be born.
} 
woman's right to control if and when to have children and how many. The next stage of the birth control movement was broader in that it encompassed contraception, abortion, and reproductive justice. Reinterpreting abortion as a necessary aspect of reproductive control and freedom became central to the feminist agenda in the second half of the twentieth century. For feminists within the Women's Liberation Movement, abortion was an absolute human right central to full equality, along with family planning for both men and women and sexual autonomy for women.

On the other hand, pro-life activists argued the procedure was a modern convenience that disturbed social cohesion and morality, and resulted in the death of a living person. ${ }^{9}$ This battle of ideologies has long kept abortion in the public eye and an active point of political contention between Republicans and Democrats in Oregon and elsewhere. ${ }^{10}$ Historians have long recognized that the personal nature of abortion procedures has influenced the debate's ability to sustain public attention for decades after the Supreme Court's ruling. An aspect of the contentious nature of abortion revolves around debates over personhood, citizenship, and individualism. ${ }^{11}$ These ideas and

\footnotetext{
${ }^{9}$ Gordon, Woman's Body, Woman's Right, 398
}

${ }^{10}$ see Williams, Defenders of the Unborn. While the abortion debate serves as a controversial topic within both dominant political parties in the United States and has become increasingly partisan, Williams argues that the liberal origins of anti-abortion sentiments is the reason for abortion remaining a topical point of contention. Williams asserts that since the pro-life argument grounded in ideas of human rights has served to continuously keep the debate contemporary.

${ }^{11}$ Kristin Luker, Abortion and the Politics of Motherhood (Berkley: University of California Press, Berkely, 1984), 1. Luker provides four main arguments in the then current abortion debate to help answer why the debate is so partisan and contentious. The first argument discusses the moral status of the embryo. The second aspect of the abortion debate is over the facts of life and how each side interprets or uses these facts. The biological facts of life are constant and known, yet how each side of the debate chooses to argue these facts differs depending on how they use the facts to support their 
arguments show up in many political debates however as views of abortion are impacted by ideologies influenced by each of these, the debate has remained particularly controversial if not volatile.

Race, class, and geography influence the discussion of abortion politics. Ideas surrounding womanhood and the capacity for bearing children have shifted and changed throughout the nineteenth and twentieth centuries just as public policy evolved in that time. Middle-class white women gained a public voice by expressing ideas of "republican motherhood" to expand their role in public life, thus expanding their own rights. ${ }^{12}$ On the other hand, women of color were coerced or misinformed when it came to contraception with some being forced into sterilization programs.

By exploring voter's pamphlets, legislative journals, and newspaper clippings in Oregon this thesis uncovers the multitude of arguments on both sides of the debate and reveals the constantly shifting political language used by both sides. These talking points were never static for pro-choice or pro-life activists. Throughout time, we see the shifting of tactics and arguments from both pro-life and pro-choice advocates within legislation, at rallies, in news columns, and on ballot measures. Though I focus primarily on

viewpoints. Pro-life activists designate personhood as beginning with the heartbeat while pro-choice activist sometimes argue that since the fetus is not breathing while it resides inside the woman's body, that its independent life does not begin until then. What aspects of life and rights each side claims as important is integral to the abortion debate. The third argument Luker makes is regarding personhood and the rights of the woman or potential child. Luker asks what rights each player has and where the rights for one conflicts with the rights of the other. Lastly, the author describes the invested social interests that all women have placed in the debate, whether these investments represent an identity in motherhood or personal autonomy, the feelings of the debate are passionate. In her breakdown of argument origins present in the US abortion debate, Luker analyzes the evolution of each movement. The changing topics and strategies used by each movement points to a politicization of abortion. Through her analysis of the abortion debate, we see a relatively young discourse that has shifted focus and players through time.

${ }^{12}$ Luker, Abortion and the Politics of Motherhood, 48. 
legislative history within the late twentieth century, I have come to realize that my research fits into the broader history of Oregon in contraceptive advocacy. Even in the early twenieth century when Oregon enforced its abortion ban, prominent activists both in the medical field and in local communities worked to ensure a woman's right to contraceptive information. Oregon has long been a relative safe haven for reproductive rights, and the advocacy of Oregon Legislators in the 1970s and 1980s just extend that legacy. $^{13}$

Roe v. Wade, the 1973 Supreme Court decision that invalidated most state abortion restrictions, was decided in a political climate that was increasingly becoming more inclusive of various identities and supportive of egalitarian civil and social rights movements. However by the 1970s, social conservative ideology was likewise on the rise and becoming more influential in the GOP as the party embraced Christian moral populism. These social conservatives asserted that the strength of the American Republic rested on the revitalization of what they saw as the nation's traditional principles in the face of social change movements led by women, minorities, gays, and lesbians. ${ }^{14}$ Prochoice activists considered the right to an abortion a civil right that all women, regardless of race or class background required and this understanding became part of Democratic Party practice and politics in most of the nation. Therefore, the pro-life and pro-choice

\footnotetext{
${ }^{13}$ Sadie Anne Adams, “'We Were Privileged in Oregon': Jessie Laird Brodie and Reproductive Politics, Locally and Transnationally, 1915-1975," (master's thesis Portland State University, 2012), 101.

${ }^{14}$ George M. Marsden, Fundamentalism and American Culture: The Shaping of Twentieth-Century Evangelicalism; 1870-1925, (New York: Oxford University Press, 1980), 141. Beginning in the 1920s, fundamentalists believed that modernizing society was turning away from God and undermining the biblical foundations of the United States. The cure to this decline was a wholesale return to the patriarchal gendered society of traditional religious life.
} 
movements increasingly aligned, in most cases, with the two dominant political parties in the United States.

My thesis is organized in a linear timeline. However each of my chapters clearly highlights an aspect of my three-part argument that illuminates the socio-political circumstances that have come together to create Oregon's pro-choice landscape. My first chapter sets the stage for Oregon's political history. I examine the century of abortion illegality in Oregon and I seek to place these events within the context of the national debate of women's choice. This chapter briefly analyzes women's reproductive activism in the era of the Oregon abortion ban and Comstock era restrictions. Even when abortion and contraceptive promotion was illegal in the state, activists performed abortions and worked to spread reproductive health information.

My second chapter begins at the dawn of abortion legalization in 1973. This chapter looks specifically at developments between 1974 and 1988. During this time, Oregon defeated all pro-life efforts to restrict abortion. This establishes my second point: pro-choice legislators successfully worked to protect abortion rights at the state level soon after abortion was decriminalized on the federal level. Every anti-abortion bill introduced to the state legislature after 1973 failed. Furthermore pro-choice lawmakers constructed and passed state legislation to make future abortion restrictions more difficult to pass. 
The pro-life movement is situated deep within Oregon's history. ${ }^{15}$ My third chapter examines pro-life efforts to pass restrictive measures in Oregon during a time when Republicans controlled the state legislature and the United States as a whole was witnessing a conservative revival. This chapter characterizes the last aspect of my argument by differentiating Oregon Republicans from the National Republican Party's pro-life agenda. Traditionally conservative legislation and libertarian ideals have always been relatively popular in Oregon. However despite the success of fiscal Republican candidates and policy in Oregon, pro-life activists failed to pass abortion restrictions. Though the late 1980s and 1990s witnessed a rise in Republican leadership in the state, and prominent pro-life activists influenced local politics, I argue that the intricacies of conservative ideology suggests Oregon Republicans do not prioritize the abortion debate like other conservatives in other states have.

I conclude my thesis with an examination of the lasting impact abortion politics had on society both in the state of Oregon and nationwide. Abortion continues to be a partisan policy issue that is litigated in the media and in the courts. Oregon voters have, since Roe, elected governors who were pro-choice or conservatives indifferent to the abortion debate. While the United States continues its conversation surrounding the ageold procedure, Oregon voters have remained supportive of their pro-choice leaders.

\footnotetext{
${ }^{15}$ For example, pro-life activists placed Ballot Measure 7 before voters in 1978 that asked voters to stop state tax funding for low-income women seeking abortions. Prochoice advocates mobilized and Oregon voters defeated the measure.
} 


\section{Chapter One \\ Pre-Roe Abortion History in Oregon 1854-1973}

Women have always sought control over their reproduction. Techniques such as douches and withdrawal were widely used throughout the centuries in order to control fertility. Reproductive competency and access to preventative techniques was not universal. Social and economic status often determined who had access to information about contraception. Poor women, often women of color, in the nineteenth century generally lacked information and access to such contraceptives. While middle and upper class women could afford effective contraceptives such as sponges, pessaries, and suppositories, low-income women relied more so on abortion after an unwanted pregnancy. ${ }^{16}$ Many women relied on undesirable and dangerous methods for controlling reproduction. In the early 1800 s, abortion in general was dangerous and procedures performed by trained physicians were not much safer than abortions performed by midwives. ${ }^{17}$ Infections were common and many abortions resulted in the death of the woman.

Oregon laws prior to 1973 followed national trends of illegality, liberalization, then ultimately decriminalization with the Supreme Court decision, Roe v. Wade. Even in the early twentieth century, Oregon displays openness to discussing reproductive politics and enacting protective legislation for women. This chapter outlines Oregon's abortion policy before Roe in relationship to the national debate. We also see in this time period a prominent presence of women's activism in Oregon, thus laying the groundwork for the network for reproductive rights activist in the years to come.

${ }^{16}$ Gordon, 69.

${ }^{17}$ Gordon, 69. 
Women controlled their reproduction with relative freedom in Oregon until 1854, when the Oregon Territorial Legislature criminalized abortion. American legal traditions followed those of the English Common Law and the "born alive" rule protected born infants and prosecuted their deaths as homicide. ${ }^{18}$ Prior to birth, English Common Law held that until "quickening," or the sensation of a woman feeling the fetus move inside her womb, a pregnancy was not recognized. This understanding differs greatly from current pro-life beliefs of life beginning at conception. Women openly sought services to "restore the mensus" or "unblock" their menstrual cycles up until they recognized the presence of fetal life with quickening. ${ }^{19}$

Reproductive health, as with most types of healthcare prior to the mid nineteenth century, was primarily tradition based and centered in the home. Even with the scientific advancements in western medicine and the broader acceptance and understanding of Germ Theory, Americans often felt more comfortable with familiar forms of herbal and home remedies that "irregular" doctors offered and professional university trained

\footnotetext{
${ }^{18}$ Rose, 3. Oregon at this time was a relatively youthful population consisting mainly of farmers and laborers. Many Oregon men had worked in California during the Gold Rush of 1848-1849 and had brought wealth back with them. See Tom Marsh, To a Promised Land: A History of Government and Politics in Oregon, (Corvallis: Oregon State University Press, 2012)

${ }^{19}$ Leslie Reagan, When Abortion was a Crime: Women, Medicine, and the Law in the United States, 1867-1973 (Berkley: University of California Press, 1997), 10. Quickening is an important notion to understand when interpreting pregnancy and birth before the mid twentieth century. Before the Supreme Court in Roe adopted the trimester system of interpreting pregnancy, the sensation of fetal movement was the commonly understood and legally recognized as the beginning of life. Women were not considered to be carrying a child until fetal movement.
} 
physicians often frightened people. ${ }^{20}$ Women typically relied on other female family members and midwives in situations of birth and abortion rather than a doctor. Families would go to the neighborhood apothecary or herbal shop for ailments rather than seeking services from what may have been a rather expensive physician.

The drive to criminalize abortion developed in tandem with the newly founded professional association for doctors, the American Medical Association (AMA). The AMA sought to create a distinct medical profession and eliminate competition in the medical field in the mid nineteenth century and focused its attention on midwifery and women's reproduction to make its mark. ${ }^{21}$ The AMA wanted to legitimize the medical profession by standardizing a science-based medical curriculum and mandatory licensing exams. ${ }^{22}$ Since the AMA's creation in 1847 , the organization worked to discredit what they deemed as unscientific methods of irregular medicine. The national campaign against abortion was twofold. It worked to both medicalize women's bodies and remove the competition to medical doctors posed by midwifery. By appealing to societal concern over declining birth rates among white, Protestant, non-immigrant women, the AMA

\footnotetext{
${ }^{20}$ Tamara Venit Shelton, "Curiosity or Cure?: Chinese Medicine and American Orientalism in Progressive Era California and Oregon," Oregon Historical Quarterly, 114, No.3 (Fall 2013), 269.

${ }^{21}$ Reagan, When Abortion was a Crime, 80. According to her research, abortion legislation has revolved around three main groups, the medical profession, the legal system, and women. For more on the anti-abortion legislation see Kermit L Hall and Peter Karsten, The Magic Mirror: Law in American History, $2^{\text {nd }}$ ed, (New York: Oxford University Press, 2009). Hall and Karsten outline the three-pronged strategy of antiabortion activists that led to the initial push to outlaw abortion. Firstly, the reeducation of American women to seek treatment from doctors offices rather than women family members. Secondly, medical societies eliminated abortion providers and midwives from the medical profession, to eliminate competition. Lastly, activists actually lobbied for abortion bans.

${ }^{22}$ Shelton, "Curiosity or Cure?," 269.
} 
raised concerns of population loss within this group as part of the campaign for the criminalization of abortion. ${ }^{23}$ With rising birthrates within immigrant communities, the AMA drew on social anxieties about the delicate hierarchy of white supremacy. During the progressive era the AMA operated in tandem with business entrepreneurs, lawmen, and politicians to regulate and enforce morality. ${ }^{24}$

Any type of non-traditional medical provider could be the target of the AMA in the late nineteenth and early twentieth century. As one example, the AMA targeted Chinese doctors and herbalists. Chinese medicine was widely used and accepted in American society soon after the first large migration of Chinese immigrants to the United States in the 1800s. Out of skepticism and fear of invasive scientific procedures for infection or ailments, some Americans turned to Chinese herbalist for many of their healthcare needs. Much like the aggressive campaigns of the AMA against abortion providers and midwives, the AMA also employed racialized campaigns against Chinese doctors in an attempt to discredit their practices and delegitimize any perceived competition to the medical profession.

The birth control pill was not available until 1960. Women in the late 1800s and early 1900s continued to employ abortion as a method of family planning, particularly women in the working-class, despite its illegality. Married women were having abortions at higher rates than single women. In early twentieth-century America, where race and gender dictated all aspects of participation in society, white native-born women were

${ }^{23}$ Michael Helquist, “'Criminal Operations': The First Fifty Years of Abortion Trials in Portland, Oregon," Oregon Historical Society, vol. 116, 1, (Spring 2015): 10.

${ }^{24}$ Michael Helquist, Marie Equi: Radical Politics and Outlaw Passions, (Corvallis: Oregon State University Press, 2015), 86. 
believed to bear the burden of childbirth to maintain the dominance of the race in the face of immigration. Accordingly, abortion was seen as counterproductive.

Oregon received statehood in 1859. In 1864 Oregon legislators revised the state's abortion statute. The law no longer drew upon the quickening doctrine and referred now to a "child" as opposed to "fetus" and charged anyone administering any "medicine, drug or substance" or the use of "any instrument or other means," for the intent of destroying the child with manslaughter. ${ }^{25}$ The law upheld exceptions to save the life of the woman, called therapeutic abortions; yet these exceptions remained vague and difficult to enforce.

Just as Oregon lawmakers conservatized the state's abortion law, the political landscape of the state was shifting. During the Civil War and preceding two years, the Union Party, a coalition of northern Democrats and Republicans, controlled the Oregon legislature. ${ }^{26}$ Oregon voted twice for President Abraham Lincoln but the stresses of reconstruction and the debate over black suffrage controlled Oregon politics. By 1868, racist campaigns by Oregon Democrats appealed to many new voters and they gained a majority in the house legislature. ${ }^{27}$

The closing decades of the nineteenth century Democrats continued to make inroads in state politics. They overturned the newly ratified $14^{\text {th }}$ amendment and denied to pass the state's $15^{\text {th }}$ amendment that would have ratified voting rights for all despite

${ }^{25}$ Journal of Proceedings of the House of the Legislative Assembly, 1864, via Helquist, “ 'Criminal Operations"', 10.

${ }^{26}$ Marsh, To a Promised Land, 52.

${ }^{27}$ Marsh, 59. Marsh contributes two main factors for the Democratic insurgence seen in Oregon in 1868. Marsh first asserts that many more people voted in general in the election of 1868, voters who favored the Democratic platform. Also, in the last two years of the civil war many border state Democrats from southern states had migrated to Oregon and supported the Oregon Democratic Party. 
race, color, or previous status of servitude ${ }^{28}$ While the debate over rights for newly freed slaves ensued, women in Oregon too were questioning their own status as citizens. Abigail Scott Duniway formed the Equal Rights Society in Albany, Oregon in 1870 and asserted that women's suffrage was key to women's equality. ${ }^{29}$ Oregon suffragists were well versed in gaining press coverage and spreading their message by newspapers and pro-suffrage weeklies. ${ }^{30}$ Duniway published the first suffrage newspaper in 1871, which during its publication was the only suffrage newspaper in the Pacific Northwest. ${ }^{31}$

While physicians pushed campaigns against abortion for their own benefit, the prosecution of such crimes evolved into mechanisms of enforcing societal norms. Despite married women being the majority of those seeking abortions, prosecutors and state officials focused primarily on prosecuting unwed women. ${ }^{32}$ By exposing and humiliating unmarried women who had received abortions, abortion law enforcement sought to police non hetero-normative sexual behavior. Men were to marry women, women were to have children, and men were to assume the financial responsibility of providing for their family. ${ }^{33}$ Notwithstanding the passage of abortion restrictions in every state in the country, millions of abortions still continued to occur annually. ${ }^{34}$

\footnotetext{
${ }^{28}$ Marsh 59.

${ }^{29}$ Marsh, 63.

${ }^{30}$ Marsh, 64.

${ }^{31}$ Marsh 64.

32 Reagan, 115.

${ }^{33}$ Reagan, 115. The author further asserts that the criminal justice system worked in tandem with the media to stigmatize abortion and enforce gender-normative behavior. Headlines often sensationalized the danger of abortion, though illegal abortion was in fact dangerous, and publicly shamed those on trial for violating abortion laws.

${ }^{34}$ Reagan, 23. Reagan documents some late-nineteenth-century doctors estimating two million abortions being performed a year.
} 
Abortions seem to have taken place routinely in early twentieth-century Oregon and nationally. One historian suggests that more than 6,000 abortions were performed each year in Portland in the early 1900s. ${ }^{35}$ However Portland witnessed only twentyseven criminal abortion cases were prosecuted between 1870 and 1920 . Of these indictments, seven resulted in a guilty verdict; prosecution of abortions cases primarily involved instances where a death resulted, when a jury could easily establish a victim and a perpetrator. ${ }^{36}$ In the very first abortion prosecution in Portland, the prosecutor charged C.G. Glass only after nineteen-year-old Mary E. Hardman died after complications from this "criminal operation." 37 The unsuccessful prosecution rate of abortion providers in Portland reveals a wider trend, in that states found it difficult to enforce criminal abortion statutes. From the early to mid-1900s, more abortion providers were arrested and charged for violating abortion laws. However even with the rise in prosecutions, the conviction rates remained low. ${ }^{38}$

It was within this legal ambiguity that prominent Oregon physician Dr. Marie Equie began performing abortions as part of her general practice in Portland. Equie opened her general medical practice in downtown Portland in $1905 .{ }^{39}$ Growing up in a working class household Equie gained an early appreciation for laborers, women, and children. ${ }^{40}$ Her practice opened just as progressive era prosecutions of abortionists were surging; nevertheless she was never charged with crimes for providing the criminal

\footnotetext{
${ }^{35}$ Helquist, "“Criminal Operations'," 12.

${ }^{36}$ Helquist, 19.

${ }^{37}$ Helquist, 6.

38 Reagan, 118.

${ }^{39}$ Helquist, Marie Equie, 55.

${ }^{40}$ Helquist, Marie Equie, 19.
} 
service to women. She may have been able to avoid indictment because she did not focus on abortion solely, instead providing abortions as part of a holistic approach to healthcare. ${ }^{41}$

Equie was not alone in her practice of abortion. For example, well-known abortion provider Ruth Barnett openly performed abortions in another downtown Portland office from 1918-1968. ${ }^{42}$ Both Equie and Barnett worked relatively freely with little attention from the Portland police. Under Barnett's expertise no women died within her fifty-year practice. ${ }^{43}$ Similarly, despite the thousands of annual abortions in Chicago during this same era, few providers faced prosecution for violating abortion statutes. ${ }^{44}$ The high abortion rate paired with the low prosecution rate suggests the relative acceptance of the procedure if not at least recognition of abortion's necessity.

For those who could not afford a professional abortion from a physician like Barnett or Equie, or a local midwife, self-induced abortions proved a viable option. While

\footnotetext{
${ }^{41}$ Helquist, Marie Equie, 92. Helquist accounts that Equie carried on her abortion practice with little regard to its illegality or how it might impact her reputation in the medical field. From Helquist's account of her life, Equie was well regarded in the medical community for her steadfast dedication to her practice and to her patients. She viewed abortion as a necessary aspect of women's reproductive health. Equie was never included in any newspaper articles regarding the procedure nor was she ever prosecuted for providing abortions, which Helquists argues enforces his idea that she did not think much of her dedication to provide them. She provided abortions to many working class and poor women for lower prices. As historians have uncovered, women from all backgrounds procured abortions and Equie provided abortions to wealthy women as well. Equie is also well known for her work as a labor and anti-war activist. Because of her involvement in healthcare and labor rights, she was widely revered in the Oregon community.

${ }^{42}$ Rickie Solinger, The Abortionist, A Woman Against the Law (New York: The Free Press, 1994). As a young woman, Barnett was the recipient of an abortion and afterwards decided to dedicate her life to women in similar straits.

${ }^{43}$ Ruth Barnett and Doug Baker, They Weep on My Doorstep (Beaverton, Or.: Halo Publishers, 1969).

${ }^{44}$ Reagan, 124.
} 
substantially more dangerous than a professional albeit illegal abortion, early twentieth century physicians regularly answered urgent house calls after self-induced abortions. ${ }^{45}$ Infections were common in these situations and it was evident to many physicians that lack of access to contraceptive information was frequently due to poverty. ${ }^{46}$ Often these women faced long-term damage from botched abortions and many died.

The Great Depression was a force that shaped the modern birth control movement. The economic hardships faced by all Americans increased the dependence on and acceptance of birth control measures during the 1930s. ${ }^{47}$ This national hardship did not go unnoticed in Oregon. One out of four working aged Oregonians was out of work and shantytowns sprang up all around the state. ${ }^{48}$ Women in Oregon across all socioeconomic backgrounds felt the need to control their reproduction. After witnessing firsthand the hardships of lack of reproductive information, Oregon physician Dr. Jessie Laird Brodie became active in local politics to improve access to contraception. ${ }^{49}$

While society at large struggled to meet the everyday needs of Americans, women in particular could be further burdened in the case of an unwanted pregnancy. The Great Depression limited resources for all families and women sought to limit the number of children they had. Progressive reformers supported social welfare projects and government programs to raise the standard of living. Reformers also became increasingly

${ }_{46}^{45}$ Adams, "We Were Privileged in Oregon,"”25.

${ }^{46}$ Adams, 25.

${ }^{47}$ Reagan, 134. The Great Depression served to strengthen the birth control movement and support for abortion for multiple reasons. Not only were the economically stressed seeking to avoid incurring more expenses on children, marriage rates fell during this time period as well. As a way to save money and survive, children were in their parents' home longer. People were marrying later and sought to reproduce less.

${ }^{48}$ Marsh, 176.

49 Adams, 25. 
aware of the high illness and death toll women faced by multiple pregnancies and botched abortions. As a remedy to this reality many reformers became politically outspoken for liberalized abortion laws. ${ }^{50}$ On the other hand, some progressives, primarily Catholics, took their support for liberal social welfare reform to extend to the unborn. Instead of supporting safe access to abortion to promote the health and wellbeing of women, these reformers believed human rights extended to all living beings and argued women should be supported by government programs both before and after giving birth. ${ }^{51}$ Additionally such reformers advocated for government aid to support children and the poor. ${ }^{52}$

Until 1936, federal Comstock Laws prohibited the distribution and dissemination of "obscene" materials, including materials containing contraceptive information. Though physicians such as Brodie wanted to establish clinics focused on providing contraceptive healthcare for women, especially those in precarious financial situations, fears of prosecution under Comstock restrictions prevented a birth control clinic from being opened in the first half of the twentieth century in Oregon. ${ }^{53}$ Brodie proposed the establishment of a birth control clinic in Portland in 1935, however the Multnomah County Medical Society concluded that there was no special need for birth control clinics due to the fact that married couples could already access contraceptives through their primary care providers. The medical society specifically stated they did not want to

\footnotetext{
${ }^{50}$ Helquist, Marie Equie, 96.

${ }^{51}$ Williams, 5.

${ }^{52}$ Williams, 5.

${ }^{53}$ Adams, 29.
} 
distribute contraceptives and information to "unmarried persons or to prostitutes." Those within the medical society thought that disseminating contraceptive information to unmarried women would violate obscenity law.

The judiciary invalidated many Comstock era restrictions on contraceptives and women continued to seek abortions and contraceptive information. The U.S. Second Circuit Court of appeals in 1936 ruled that Comstock Laws were not meant to prevent "conscientious and competent physicians" from providing their patients with care aimed at improving their wellbeing. ${ }^{55}$ The reversal of prohibitions on the distribution of materials relating to birth control exemplified changing public perception of contraception and by extension abortion from a vice to an essential aspect of personal and family life. The increased demand for abortions during national economic hardship brought a rapid increase in the scientific understanding of and technological advances within the practice. Despite the AMA's initial opposition to abortion, many physicians (and nonprofessionals) soon realized that abortion services could be a lucrative business. Some physicians even obtained additional training in abortion procedures, and this led to the specialized manufacture of new tools specifically for the procedure ${ }^{56}$ Furthermore, the discovery and widespread use of antibiotics significantly reduced the risk of illness and death from most surgeries and illness making abortion and other operations less dangerous.

\footnotetext{
${ }^{54}$ Adams, 33.

${ }^{55}$ Adams, 38.

${ }^{56}$ Reagan, 147.
} 
Yet another victory for the birth control advocates came in 1937 when the AMA recognized birth control as a legitimate aspect of health care. ${ }^{57}$ Nevertheless, contraception and abortion still held class and race implications. While it is true that women from all walks of life need abortions, access and resources do still dictate the options available to poor and minority women. Self-induced abortions caused more complications and hospitalizations than did those induced by physicians or midwives. Since poor women and minority women were more likely to try to self-induce abortions they suffered more complications. ${ }^{58}$ The dangerous reality of abortion bans contributed to the freedom abortion providers experienced and also emboldened many to lobby their local governments to liberalize abortion statutes.

\section{Liberalizing Abortion Laws}

The 1950s ushered in a new era of political involvement on the part of young people, minorities, and women across the nation. Views on birth control took on a new albeit class-skewed breadth in the middle of the twentieth century. Birth control clinics were opening across the country, primarily aimed at servicing poor and AfricanAmerican communities. ${ }^{59}$ Oregon too at this time first began seeing shifts in her political makeup. For much of the early twentieth century, Oregon had consistently voted Republican. However Democrats raised voter turnout and took control of many

\footnotetext{
${ }^{57}$ Reagan, 134. Also, Reagan asserts, $80 \%$ of women at this time approved of birth control.

58 Reagan, 132.

59 Adams, 97.
} 
traditionally Republican seats in the election of 1956. Republicans only held one seat after this election. ${ }^{60}$

By the mid-1960s population control became popular public policy. Following post-war social policy focusing on an anti-poverty agenda, birth control became widely accepted as a means of controlling the swelling population, particularly in poorer parts of the world. Resources in relation to family size and population became the central selling point to the broader American public. ${ }^{61}$ More progressive leaning politicians and particularly Democrats were gaining control statewide. The death of US Senator Richard Neuberger in 1960 sparked the campaign of his wife Maureen to fill his seat in the 1961 term. Democrat Maurine Neuberger succeeded her husband when she won 54\% of the vote, becoming the first elected female to the US senate from Oregon. ${ }^{62}$ The emergence of a successful two-party system in Oregon created a landscape ideal for contentious presidential campaigns. Presidential nominees regularly campaigned in Oregon. ${ }^{63}$

The growing influence of the Democratic Party in Oregon culminated in the reapportionment of 1962, when new house and senate districts were drawn. Throughout most of Oregon history, districts favored more rural and less populated areas of Oregon,

${ }^{60}$ Marsh, 240. However Oregon did vote Republican for president in this election. The phenomenon of rising Democratic power in Oregon at this time is what Marsh describes as the beginning of a "true two-party state"

${ }^{61}$ Adams, 98.

${ }^{62}$ Kimberly Jensen, "Maurine Neuberger 1906-2000," Oregon Encyclopedia, last modified March 17, 2018, accessed November 25, 2018, https://oregonencyclopedia.org/articles/neuberger_maurine_1907_2000 /\#.XAnr45NKg1 I. The same year Neuberger won her senate seat Republican Mark Hatfield won the Governorship.

${ }^{63}$ Marsh, 244. 
giving southern and eastern Oregon more representation in politics. ${ }^{64}$ After reapportionment, eastern Oregon lost four legislative districts when those districts shifted to more populated regions within the Willamette Valley and Portland. This enforced the political power of Democratic voters. ${ }^{65}$

Portland activists took advantage of the favorable political climate and worked to establish the official Planned Parenthood Association of Oregon, Inc. (PPAO) in 1963, nearly thirty years after the first proposed clinic was rejected. Dr. Alan Guttmacher, the president of the national Planned Parenthood Association, took particular interest in the Portland committee. ${ }^{66}$ The physicians working at the first Portland clinic were all volunteers and despite concerns from the national association, the clinic opened with around one thousand dollars in the bank. ${ }^{67}$ It is estimated that one-third of the OB/GYN/s in the area volunteered to work in this clinic. ${ }^{68}$

This eagerness to open the clinic and the immense amount of support the clinic represents the community's support towards reproductive health in the state. Oregonians had previously been accustomed to quietly acknowledging women's contraceptive care, such as with Equie or Barnett's abortion practices. Now the state openly displayed its acceptance for supporting women's reproductive freedom. Even in an era where abortion

\footnotetext{
${ }^{64}$ Marsh, 267.

${ }^{65}$ Marsh, 267. This shift is notable because Oregon's progressive policy strength can be linked to this reapportionment. Many more partisan debates can be viewed on an Oregon voter map with progressive leaning Democrats encompassing the densely populated Willamette Valley while conservative Republicans occupy the rest of the state. As the Willamette Valley became more and more populated throughout the twentieth century, the political power in this region broke the threshold to demonstrate true political influence in the entire state.

${ }^{66}$ Adams, 100.

${ }^{67}$ Adams, 101.

${ }^{68}$ Adams, 106.
} 
was illegal and birth control was not a topic of public discourse. Within the first year of PPAO's opening, several inquiries from Umatilla, Yamhill, and Washington counties came in asking for help establishing their own birth control clinics. ${ }^{69}$

A decade after activists began pushing for more liberalized abortion laws, a counter movement started to emerge. Evangelical Christian leaning conservatives concerned with the growing demand for access to legal abortion formed a movement that was committed to the reversal of these liberal abortion laws. These new pro-life groups sought to work together in defense of "family and Christian sexual morality."70 Though the various groups who identify as pro-life have a common interest in restricting or eliminating abortion access, in many cases, abortion is the only policy these groups agree upon. For example, though Evangelical and Catholic based pro-life groups share the antiabortion agenda, they often disagree on issues surrounding euthanasia, embryo experimentation, and capitol punishment. ${ }^{71}$ Catholic based groups identify as pro-life, in all aspects of American policy, while Evangelical groups are pro-family, and are less concerned with America's deadly foreign policy or the death penalty. Though these groups can support one another in these mutual interests, actually creating a meaningful coalition has proven difficult. ${ }^{72}$

${ }^{69}$ Adams, 109.

${ }^{70}$ Durham, The Christian Right, the Far Right and the Boundaries of American Conservatism, (Manchester: Manchester University Press, 2000), 85.

${ }^{71}$ Durham, The Christian Right, the Far Right, and the Boundaries of American Conservatism, 86.

72 The coalition between various Christian denominations in the 1970s is often referred to at the Moral Majority. Leaders of this coalition hoped to create an ecumenical coalition that worked as a block to promote certain political agendas. Neil argues, that though many religious conservatives could cooperate on issues of abortion and the ERA, the Moral Majority was mostly a misnomer for denominations continued throughout this 
While Roe was a singular event that forever changed American women's reproductive freedom, it is essential to locate the decision within a longer line of Supreme Court jurisprudence. Roe did not end the abortion debate but rather reinvigorated it. Furthermore, Roe followed many Supreme Court decisions where the justices ruled on state intervention in women's reproductive care. Griswold v. Connecticut (1965) challenged state statutes that restricted married women's access to contraception. The executive director of the Planned Parenthood League of Connecticut, Estelle T. Griswold, along with the medical director of the league, violated state law that banned counseling married couples about birth control and outlawed distributing contraceptives to them; this act of defiance lead to their arrest.

The Court ruled in favor of Griswold, and argued that Connecticut had over extended its reach in banning contraceptives and counseling to married couples, stating that the decision to extend ones family was intimately personal, and protected by the privacy doctrine as interpreted in the fourth amendment. ${ }^{73}$

Similarly, Eisenstadt v. Baird in 1970 challenged a Massachusetts statute that forbade the distribution of contraception to single women by anyone besides a pharmacist. A federal district court granted habeas corpus to William R. Baird, the petitioner, finding that the Massachusetts law was unconstitutional. The Sheriff of the county appealed this motion and the case went to the Supreme Court. The state convicted Baird of a felony after he provided vaginal foam to unmarried women.

time to work more so on an individual level than in tandem. A book that reviews these coalitions is See Neil J. Young, We Gather Together : The Religious Right and the Problem of Interfaith Politics, (New York: Oxford University Press, 2016).

${ }^{73}$ Griswold v. Connecticut., 381 US 479 (1965). 
He had done so to assert the rights of unmarried people to gain access to contraception in a direct challenge to the state statute. ${ }^{74}$ The Supreme Court held that the Massachusetts statute violated the Equal Protection Clause of the fourteenth amendment to the US Constitution and that no rational basis existed for treating married and unmarried people differently. ${ }^{75}$ The right to privacy to be free of unwarranted intrusions into whether to have children was the same for married and unmarried women alike and noted that unmarried persons had as great an interest in avoiding the spread of harmful sexually transmitted diseases. ${ }^{76}$

The Baird case highlights how the Massachusetts legislature made clear their intentions on controlling certain sexual relations. By rejecting a law that made sexual relations out of wedlock dangerous in opening up possibilities for unwanted pregnancies, the Supreme Court overturned a statute that implicated women's health and enforced gender roles. In these cases, the Court rejected constitutional interpretations that bound women to marriage. By 1973, abortion laws nationwide were liberalizing.

Activists dedicated to making abortion legal pushed to change their state law at the grassroots level. Colorado liberalized its abortion ban in 1967. As did California-a bill signed by then Republican Governor Ronald Regan, and Washington liberalized its abortion law in 1970. Oregon, too, followed this progressive trend and amended its

\footnotetext{
${ }^{74}$ Eisenstadt v. Baird., 405 US 438 (1972). William Baird provided the contraceptive vaginal foam to women after he held a lecture at Boston University about overpopulation. As the Massachusetts law provided only authorized distributors and pharmacists to distribute such contraceptives, Baird was neither; he was in violation of the law. For more on the background of this case and to hear the oral argument audio see, "Body Politics: Eisenstadt v. Baird", Oyez, https://www.oyez.org/cases/1971/70-17 ${ }^{75}$ Eisenstadt v. Baird., 405 US 438 (1972).

${ }^{76}$ Eisenstadt v. Baird., 405 US 438 (1972).
} 
abortion ban in 1969, allowing for abortion in certain circumstances. However this liberalized abortion law was passed by the Oregon congress in lieu of a complete legalization of the procedure.

As the only woman in the 1969 state senate, Betty Roberts introduced a bill to legalize the procedure so long as a physician performed it. ${ }^{77}$ Roberts called on testimony from various psychologists, physicians, and women's reproductive advocates. It is notable though that at this time arguments in favor or legalizing abortion primarily addressed fiscal and emotional hardships of unwanted pregnancy. Roberts remembers in her memoir that the 1969 debates over her bill were missing discussion on the principle of choice or that women had the fundamental right to make choices regarding her own body; arguments we later hear taken up by the feminists in the Women's Liberation Movement. ${ }^{78}$ Roberts' bill did not pass the Oregon senate, it was held up with a 15-15vote tie.

The bill that did gain enough votes to pass into law was one introduced by Republican state Senator Dick Hoyt. This liberalized abortion bill made it legal for women to obtain abortions in cases of rape, incest, fetal anomaly or when it threatened her life. Yet this new bill did require parental consent for minors and a husband's consent for women living with their husbands. ${ }^{79}$ After her sponsored bill aiming to completely overturn Oregon's abortion ban failed to pass the state legislature Roberts co-filed a lawsuit in 1971, Benson v. Johnson challenging the constitutionality of Oregon's new

${ }^{77}$ Betty Roberts with Gail Wells, With Grit and by Grace: Breaking Trails in Politics and Law, A memoir, (Corvallis: Oregon State University Press) 2008, 111.

${ }^{78}$ Roberts and Wells, With Grit and by Grace, 114.

${ }^{79}$ Roberts and Wells, 114. 
abortion statute. ${ }^{80}$ The plaintiffs in this suit argued that the 1969 law was vague, unenforceable, and ultimately unconstitutional. Plaintiffs also argued that the law violated rights to privacy between a doctor and their patient and that the law made it impossible for doctors to provide the highest level of treatment to their patients. ${ }^{81}$ After filing the suit Roberts would have to wait years to argue her case; and after Roe invalidated all state abortion bans in 1973, the Benson case was deemed moot.

Oregonians elected Tom McCall as governor in 1967. Well known in Oregon since the release of his 1962 documentary on pollution in the Willamette Valley, McCall was popular statewide amongst Republicans, Democrats, and Independents. This popularity helped him easily win reelection in $1970 .{ }^{82}$ McCall's popularity is contributed in part to his progressive policy agenda, most memorably his dedication to environmental protection, a commitment that put him at odds with many more mainstream Republicans. ${ }^{83}$ In 1971 McCall's administration oversaw the passage of numerous environmental protections and initiatives such as the bottle bill, the bike bill, state highway beautification, and the solid waste management act. ${ }^{84}$ The success of Governor McCall is not unusual for Oregon at this time. Not only was McCall a progressive Republican but elections consistently proved Oregon's acceptance of two-party leadership.

${ }^{80}$ Roberts and Wells, 123. Background on the case

${ }^{81}$ Roberts and Wells, 123.

${ }^{82}$ Marsh, 306.

${ }^{83}$ Marsh, 278.

${ }^{84}$ Marsh, 307. The bike bill allocated one percent of state highway funds to construct bike paths and the highway beautification bill sought to reduce the number of billboards across Oregon's scenic highways. Marsh further asserts that McCall's environmentalism was rooted in his belief that the health of Oregon's wildlife and wilderness was essential of the quality of life for voters. 
The GOP held the house while Democrats controlled the state senate the same year Oregonians elected McCall as Governor. Oregon voted Republican for president in 1968 yet in 1971 Democrats gained control of both chambers of the state legislature. The shifting and yet functioning two-party system of Oregon in the last few decades of the twentieth century points to a less partisan nature of politics. Not only were Democrats gaining more influence in the state but also Republicans consistently held moderate to even progressive views on domestic policy. This trend continues through the close of the twentieth century as moderate voters continuously avoided socially conservative legislation policy.

\section{Legalizing Abortion}

The Court faced the abortion question at a time when the debate captivated the country as part of the larger discussion of women's liberation. According to pro-life conservative activists, society relied upon traditional family structures where women bore and raised children. Abortion thus was an affront to this commitment. According to socially conservative women activists such as Phyllis Schlafly, women's political power should not be focused on excising societal and economic independence, but to validate and protect their traditional position as wife and mother. ${ }^{85}$

${ }^{85}$ Catherine E. Rymph, Republican Women: Feminism and Conservatism from Suffrage through the Rise of the New Right (North Carolina: Chapel Hill, 2006), 241. The Court has historically perpetuated the socially conservative interpretation of women's protective status, giving social conservatives such as Schlafly judiciary support and recognition. Linda K. Kerber, in: No Constitutional Right to be Ladies: Women and the Obligations of Citizenship, (New York, NY: Hill and Wang, 1998), describes this history in depth. Kerber argues that statutes shrouded as protective legislation for women actually worked to disenfranchise and separate women before the law. Legislation framed 
It was in these critical years of the Women's Liberation Movement that two Texas based attorneys, Linda Coffee and Sarah Weddington, set their sights on overturning that state's abortion ban. Young Norma McCorvey sought to terminate her unwanted pregnancy and faced opposition in her effort to do so as a result of Texas' restrictive abortion law. McCorvey faced opposition from her doctor, who cited the state's nineteenth century abortion ban and refused to perform the procedure. ${ }^{86}$ Similar to the abortion statutes of many states, the Texas law made the procuring of an abortion illegal except to save the life of the mother. McCorvey's doctor instead referred her to an adoption attorney, who in turn, knowing the intentions of Weddington and Coffee, introduced the two parties. ${ }^{87}$ The lawsuit that followed became Roe v. Wade with McCorvey adopting the pseudonym Jane Roe for the proceedings.

In the decades directly preceding Roe, the Court's rulings worked to broaden women's control over her reproduction. However looking further into Supreme Court history, The Court tended to enforce traditional patriarchal gendered roles. For example, twelve years prior in1961 the Court heard Hoyt v. Florida; a challenge to Florida's exemption for women from serving on juries. The Supreme Court held that the clause was not discriminatory towards women. Justices expressed fear of imposing civil responsibilities on women outside the domestic sphere since women were at "the center

as "protective" of women categorizes the genders, and that categorization within the American legal system historically has later been interpreted to remove various rights from women.

${ }^{86}$ Lee Epstein and Thomas G. Walker, Constitutional Law for a Changing America: Rights, Liberties, and Justice, $9^{\text {th }}$ ed. (Los Angeles: CQ Press, 2016), 403. The Texas abortion ban was passed in 1857, and was later revised in 1879 .

${ }^{87}$ Epstein and Walker, Constitutional Law for a Changing America, 403. 
of home and family life." ${ }^{88}$ In Hoyt, The Court made clear their belief that the "special responsibilities" women hold within their home should not be imposed upon by civic duties such as serving on juries. The justices still idealized women as mothers who had explicit responsibilities to her husband and family, a responsibility so sacred that her civic duties did not interfere.

It is within this legal legacy that McCorvey's attorneys challenged Texas' abortion ban. The two attorneys contested the ban on many fronts. They argued the ban infringed on citizens' right to privacy, women's equality, and due process. ${ }^{89} \mathrm{~A}$ threejudge district court ruled in McCorvey's favor, primarily relying on constitutional privacy doctrine. However, the district court did not overturn the Texas statute and in turn, McCorvey and her attorneys appealed to the Supreme Court. ${ }^{90}$ Attempting to argue that abortion was a fundamental right under the Griswold doctrine, Coffee and Weddington teamed with the American Civil Liberties Union (ACLU) and other pro-choice groups to prepare opening statements and briefs. ${ }^{91}$

${ }^{88}$ Hoyt v. Florida., 368 US 57 (1961). The majority opinion went on to assert, "Despite the enlightened emancipation of women from the restrictions and protections of bygone years, and their entry into many parts of community life formerly considered to be reserved to men, woman is still regarded as the center of home and family life. The court cannot say that it is constitutionally impermissible for a state, acting in pursuit of the general welfare, to conclude that a woman should be relieved from the civic duty of jury service unless she herself determines that such service is consistent with her own special responsibilities.

${ }^{89}$ Epstein and Walker, 403

${ }^{90}$ Epstein and Walker, 403

${ }^{91}$ Epstein and Walker, 403. Just as Griswold's attorneys successfully established the personal and private nature of family planning, Weddington and Coffee attempted to build off of precedent in linking their argument against the abortion ban to the same premise. While Court precedent held that birth control could only be managed by women, the attorneys in Roe went a step further to argue that pregnancy and abortion was such an intimate matter, that the privacy doctrine established in the fourth amendment, ninth, and 
Coffee and Weddington argued that unless Texas could provide a compelling and narrowly tailored interest in infringing on a woman's privacy, the law was unconstitutional. Furthermore, as Weddington and Coffee proved with sociological evidence, restrictive abortion laws had negative effects on both physical and mental health of women. ${ }^{92}$ The Court too, acknowledged these arguments:

Maternity, or additional offspring, may force upon the woman a distressful life and future. Psychological harm may be imminent. Mental and physical health may be taxed by childcare. There is also the distress, for all concerned, associated with the unwanted childe, and there is the problem of bringing a child into a family already unable, psychologically and otherwise, to care for it. ${ }^{93}$

Counter to Weddington and Coffee, in an attempt to prove a state interest in protecting a fetus, the state of Texas focused on presenting the "humanness" of the fetus by showing embryonic photos from various stages of gestation. However by focusing on the health complications imposed by an unwanted pregnancy upon the woman, and refusing to acknowledge the personhood of a fetus, the Court rejected Texas' argument of preserving the life of the unborn.

Only seven justices were present at the first oral arguments of Roe. President Richard Nixon's two new appointees, Lewis F. Powell Jr. and William Rehnquist had yet to take the bench. ${ }^{94}$ After the initial oral arguments, the justices disagreed on how the Court should outline the opinion. Though the majority believed state abortion restrictions to be unconstitutional, no consensus existed as to why, resulting in Roe being reargued in front of all nine justices on October 11, 1972, in conjunction with another abortion case,

fourteenth amendments extended to protect a woman's choice of whether or not to continue a pregnancy without interference from the state.

92 Epstein and Walker, 403.

${ }^{93}$ Roe v. Wade., 410 US 113 (1973).

${ }^{94}$ Roe v. Wade., 410 US 113 (1973). 
Doe v. Bolton. ${ }^{95}$ The decision of the Court ultimately focused on the constitutional right to privacy as an extension of the fundamental right to liberty. ${ }^{96}$ Grounding the right to privacy firmly within the bounds of the Constitution, the Court ruled that this fundamental right covered a woman's personal decision to choose whether or not to continue a pregnancy. ${ }^{97}$

The 7-2 decision legalizing abortion did allow states to legislate and regulate abortion access after the first trimester of a pregnancy. As the Court made clear, “[A]ppellant and some amici argue that the woman's right is absolute and that she is entitled to terminate her pregnancy at whatever time, in whatever way, and for whatever reason she alone chooses," yet the Court also voiced their opposition to such a absolute right. ${ }^{98}$ The decision continued, "[A] state may properly assert important interest in safeguarding health, in maintaining medical standards, and in protecting potential life" 99

Following suit, many states immediately enacted regulations on abortions, thus beginning the long legal battle between pro-choice and pro-life advocates. Some states have regulated the procedure out of virtual existence for many women by the forced closure of clinics due to costly regulations. Seven states currently rely on a single abortion provider and Mississippi alone has enacted over three hundred restrictions related to abortion in the past decade ${ }^{100}$ Instead of ending the debate, the years after Roe

${ }^{95}$ The "Does" were a married couple arguing that state abortion statutes threatened the wife's life because if she were to become pregnant, her health would be in danger. However the Court ultimately dismissed this case due to a lack of legal standing.

${ }^{96}$ Roe v. Wade., 410 US 113 (1973).

${ }_{97}^{97}$ Roe v. Wade., 410 US 113 (1973).

${ }_{98}^{98}$ Roe v. Wade., 410 US 113 (1973).

${ }^{99}$ Roe v. Wade., 410 US 113 (1973).

${ }^{100}$ Rose, 102. 
have proven extremely contentious. Given the reality many women face in southern or mountain states with restricted access to abortion, the fact that Oregon has avoided passing any laws on the procedure is notable.

After the Supreme Court invalidated many state abortion laws, including Oregon's in 1973, House Bill 2831 introduced by Republican Representative Hector Macpherson proposed that, "A woman may obtain the termination of her pregnancy by appropriate means upon her request. ${ }^{, 101}$ Furthermore, Democratic state representatives Vera Katz, Stephen Kafoury, and Lawrence Perry sponsored HB 2929 in the same regular session. This bill authorized women "to obtain abortion on advice of physician." ${ }^{, 102}$ The committee to the judiciary introduced SB 698 seeking to revise the state abortion law. This bill sought to formally legalize all abortion up to the first 180 days of pregnancy. ${ }^{103} \mathrm{HB} 3282$ of the same year similarly sought to revise the current abortion law to allow for abortion during the first six months; however the bill distinguished between abortions before and after 150 days of gestation. ${ }^{104}$ All of these

1011973 Legislative Journal, 1973 Regular Session, Oregon State Archives, Salem, OR. The first reading of this bill took place in March, 1973 with a second reading the following day. This bill was referred to the committee for environmental land use and tabled later in the year.

1021973 Legislative Journal, 1973 Regular Session, Oregon State Archives, Salem, OR. HB 2929 had a first reading on February 17 and a second reading February 28. The bill was sent to the committee for environmental land use and tabled later in the year.

1031973 Legislative Journal, 1973 Regular Session, Oregon State Archives, Salem, OR. First reading of SB 698 took place March 20 and the second reading was on March 22. The bill read, "“Revises law relating to abortion. Provides that licensed physician is justified in performing an abortion at any time during first 180 days of pregnancy. Permits an abortion after $180^{\text {th }}$ day of pregnancy only to preserve life or health of pregnancy woman or if there is substantial risk that child would be born with serious physical or mental defect." The bill later died in the senate judiciary committee upon adjournment.

${ }^{104} 1973$ Legislative Journal, 1973 Regular Session, Oregon State Archives, Salem, OR 
laws were introduced after the Supreme Court decided Roe, signaling a widespread bipartisan attempt to standardize Oregon law with this ruling. However none of these bills reached a vote so therefore can be interpreted as a minor legislative priority.

\section{Oregon Women and the State Legislature}

Reflecting American women's participation and activism of the late 1960s and 1970s, in 1973 a group of bipartisan women legislators worked to pass eleven explicitly feminist bills into law. ${ }^{105}$ Many of these legislators were newly elected. Beginning in the 1950s, women legislators were an important strategy to the Democratic Party. ${ }^{106}$ The Oregon Democratic Party often had trouble finding viable male candidates who had the time to serve and who could afford the low salary of the state legislature. By supporting women candidates for these state legislative seats, Democrats were able to gain control of the Oregon Legislature from the mid 1950s through to the 1960s. However the state capitol was slow to change. In 1969, as the only woman state senator, Roberts had to use the women's restroom as it was simultaneously being used as the nurse's office. ${ }^{107}$ By the Oregon Democratic Party recruiting and supporting women for state legislature seats, the party knowingly or not, planted the seeds for a pro-women ultimately pro-choice legislature.

These state representatives were new to lawmaking, yet they proved successful at their job. Initially as more women ran for office in the 1950s and early 1960s, the policy

${ }^{105}$ Tara Watson and Melody Rose, "She Flies With Her Own Wings: Women in the 1973 Oregon Legislative Session," Oregon Historical Society, 111, no.1, (Spring 2010): 38.

${ }^{106}$ Watson and Rose, "She Flies With Her Own Wings," 42.

${ }^{107}$ Roberts and Wells, 109. 
agenda pursued was not a feminist one. ${ }^{108}$ However as time went on these lawmakers were able to sponsor and pass legislation aimed at enshrining abortion rights, promoting public education, and overturning sexist labor laws. For example, House Bill 2116 in 1973 prohibited discrimination based on sex or marital status in public accommodations, housing, and education. ${ }^{109}$ The Oregon Council for Women's Equality regularly held listening sessions so concerned citizens could voice their opinions on policy priorities. ${ }^{110}$ This council wanted to discuss strategy for ratification of the Equal Rights Amendment (ERA) as well as the proposal of childcare and family planning bills.

The fact that these newly elected women legislators pursued so-called feminist policy is predictable. Based on the voting pattern of women legislators across the country, women are more likely to support measures involving women, children, education, and social welfare and labor. Prior to 1970, when women were scarcely elected to public office, the policy agenda pursued by women legislators could be interpreted as extensions of socially acceptable areas of expertise of women because for the most part, society frowned upon women in the public sphere. ${ }^{111}$ Women sat on committees that coincided with their traditional roles of homemaking and education. Notably, Oregon state lawmaker Maureen Neuberger in 1951 donned an apron on the floor of the state legislature and demonstrated with a mixing bowl and sticks of margarine the strenuous process of mixing coloring into margarine by hand. She did so in order to

\footnotetext{
${ }^{108}$ Watson and Rose, 44.

1091973 Legislative Journal, 1973 Regular Session, Oregon State Archives, Salem, Oregon.

110 "Women's Priorities in the 1973 Legislature," box 8, folder 5, Gretchen Kafoury Papers, Portland State University Special Collections, Portland.

${ }^{111}$ Sue Thomas, How Women Legislate, (New York: Oxford University Press, 1994), 7.
} 
gain support for her bill to repeal the state ban on colored margarine, a policy agenda fitting for a woman of that time. ${ }^{112}$

However as society became more accepting of women in the public sphere, women legislators too became more willing to openly pursue and support explicitly feminist agendas and policy that promote the advancement of women, children, and families. For example women are more likely than men to support public day care and liberal abortion laws. ${ }^{113}$ In 1973, the legislature spurred by these motivated female lawmakers had a seventy-nine percent success rate in the state senate and a fifty-five percent success rate in the state house of representatives. ${ }^{114}$ The success of women legislators, primarily progressive women, has continued throughout time. Between 1981 and 2014, Oregon women in the state legislature increased twelve percent while Republican women representation in the state legislature has fallen three percent in the same time period. ${ }^{115}$

Even when abortion was illegal in the state, women's reproductive rights activists worked both on a grassroots level and within state agencies to ensure women had access to contraceptive information and healthcare. Furthermore, as more and more women ran for elected office starting in the 1950s in Oregon, more explicitly feminist policy plans

\footnotetext{
${ }^{112}$ Watson and Rose, 44.

${ }^{113}$ Thomas, How Women Legislate, 58. see Estelle B Freedman, No Turning Back: The History of Feminism and the Future of Women, (New York: Ballantine Books, 2002). Freedman outlines initial widespread opposition to identifying with feminism. Often people associated feminism with extremism and a rejection to female difference. Though many women reformers opposed the label, not all did. As women's rights advocacy progressed through the mid twentieth century and the priority shifted to full social and legal equality, more reformers and activists identified with feminism.

${ }^{114}$ Watson and Rose, 50.

${ }^{115}$ Elder, 382.
} 
were implemented, exemplifying Oregon's long history of support for women's reproductive health, which we will later see transformed into support for abortion rights. Though Oregon followed the legal trends of the country as a whole during the first campaigns against abortion, its pro-choice sympathies became well established by the early twentieth century with the advocacy of prominent contraceptive health activists. This progressive streak continued through the legalization abortion and into contemporary times. While the state enforced albeit unsuccessfully an abortion restriction until Roe invalidated state laws, Oregon lawmakers and voters prevented any new abortion restrictions from coming to fruition. 


\section{Chapter Two \\ Establishing an Infrastructure for Reproductive Freedom; Oregon Abortion Politics 1974-1988}

As mainstream political parties in the United States shifted platforms and priorities, the Republican Party revised their agenda, particularly emphasizing the importance of Christianity and "family values." Increasingly influenced by tradition, the Republican Party targeted abortion access after Roe. While Republican legislators and community organizers in the South, Great Plains, and Mountain states worked with success to pass abortion restriction legislation, the often-Democratic controlled Oregon legislature rejected any introduction of abortion restrictions. Democratic power had been rising steadily throughout the latter half of the twentieth century in Oregon.

Additionally, as Democrats controlled much of the state legislature in the 1980s, grassroots pro-life conservatives failed at passing any abortion restrictions through ballot initiative. ${ }^{116}$ As shown previously, Oregon's reproductive political activism dates back to the early twentieth century and continued into the latter half of the century with the election of many pro-choice women into the state government. This groundwork proved important to the maintenance of a political landscape protective of reproductive rights. This chapter analyzes the years directly after Roe $v$. Wade by outlining how Oregon politics responded to the national debate over abortion policy. Thus continuing the legacy of supporting reproductive choice, the Oregon legislature protected abortion rights in a

\footnotetext{
${ }^{116}$ A main aspect of my argument is that Oregon Republicans have differentiated themselves from the broader Republican Party by avoiding the abortion debate. As a means of separating two viewpoints within the same political party, I employ "pro-life conservative" to describe social conservatives who overwhelmingly identify with the Republican Party. When referring to voters who identify with the Republican Party historically but not necessarily with the pro-life movement, I interchangeably use the "Republican" or "conservative".
} 
series of political maneuvering; and in so doing, made the possibility of passing any state abortion restriction much more difficult.

Oregon not only is the earliest user of a direct democracy ballot measure system but also uses the system more than other states. ${ }^{117}$ Historically, populist movements have utilized direct democracy the most, particularly at the beginning and the end of the twentieth century. These large-scale movements utilizing direct democracy came at times when activists sought to change state laws to reflect their own moral beliefs, an observation described as "populist moralism." 118 The first widespread use of Oregon's referendum system began at the turn of the twentieth century, when William S. U'Ren formed the Joint Committee on Direct Legislation. This committee, along with large swaths of the community, wanted to "circumvent the corrupt interests that seemed to control the votes of legislators." 119 Citizens wanted to end corruption in their government, and direct democracy was viewed as a tool to do so. Seventy years later, pro-life conservatives relied heavily on direct democracy in attempts to restrict access to abortion.

The pro-life stance taken up by the Christian Right as it became more powerful in the Republican Party, has served to split women and feminists along partisan lines. Into the 1970s, feminism was popular among Republican women. In 1975, the chair of the Republican National Committee, Mary Louise Smith, supported the ERA and the president of the National Women's Political caucus, Republican Audrey Rowe Colom,

${ }^{117}$ Lawrence M Lipin and Willian Lunch, "Moralistic Direct Democracy: Political Insurgents, Religion, and the State in Twentieth-Century Oregon," Oregon Historical Quarterly, 110, no. 4, (Winter 2009): 514.

${ }_{118}$ Lipin and Lunch, "Moralistic Direct Democracy," 514.

${ }^{119}$ Lipin and Lunch, 515. 
identified as a feminist. ${ }^{120}$ The newly elected women in the 1973 Oregon regular legislative session spanned the political spectrum, and their ideological diversity factored into their success.

Yet by 1975, Christian mobilization into national prominence effectively marginalized Republican feminists by moving the party away from its support of women's rights and feminism by targeting the ERA and abortion. Additionally, the representation of women within the Republican Party has declined as the platform has become increasingly opposed to feminism. As social conservatives increased their influence on the GOP, the enforcement of traditional gender roles became a priority of the party. ${ }^{121}$ This societal shift is proven to later impact women's professional participation within the party. In accordance to this notion of traditionalism, women's work in the public sphere and in leadership positions can be interpreted as a direct affront to the natural role of women as mothers and homemakers. Conversely, the Democratic Party embraced feminism and women's liberation, leading to an increase in women's participation in the party. ${ }^{122}$ Even as the Republican share of legislative seats have increased, the number of Republican women in state legislatures has stagnated. ${ }^{123}$

\footnotetext{
${ }^{120}$ Rymph, Republican Women, 1.

${ }^{121}$ Laurel Elder, "Contrasting Party Dynamics: A Three Decade Analysis of the Representation of Democratic Versus Republican Women State Legislators," The Social Science Journal, 51, (2014): 379.

122 Elder, "Contrasting Party Dynamics," 380. It is also important to remember that some do identify as both pro-life and a feminist. Much like early Catholic pro-life advocates, pro-life feminist support programs for pregnant women and children. Durham in, The Christian Right, the Far Right, and the Boundaries of American Conservatism, discusses the origins of the pro-life feminist movement of the 1970s. However the mainstream feminist organization still rejects pro-life arguments.

${ }^{123}$ Elder, 378. As Elder points out, from the 1980s through the early 2000 s women had gained more representation in aspects of society such as education and career, however
} 


\section{The Christian Right in the United States and Oregon}

Historians have already examined the influence of evangelicalism within the realignment of American politics. Opposition to modernism is fundamental to the Christian traditionalism that developed nationally in the latter half of the twentieth century that targeted women's, minority, immigrant, and LGBTQ rights. ${ }^{124}$ Followers of the fundamentals of faith, religiously influenced conservatives denounced post-WWI's modern society and shifting ideals of traditionalism, morality, sexuality, and gender. In response to communism in the 1950 s and 1960 s, we find that a more secular conservative activism conflated national fears with the liberal agenda of equality in education and society, and led to calls for their own brand of freedom against an ever-encroaching federal government. ${ }^{125}$ They took the growing global tensions as affirmation that the world was in fact, coming to an end, and it is their jobs as followers of the Christian faith to promote a society worthy of Jesus's second coming. While early fundamentalists within the Christian Right laid the groundwork for the evangelically influenced conservative philosophy of the modern Republican Party, it was local organizers in the 1980s and 1990s who took to the Oregon streets; becoming the ground force of social conservatism within the state. ${ }^{126}$ Socially conservative activism worked in middle class

women have declined or remained stagnant as a percent of Republican state legislators in many states. In contrast, Democratic women representation has risen in the same time period in every state.

${ }^{124}$ Marsden, Fundamentalism and American Culture, 3.

${ }^{125}$ Lisa McGirr, Suburban Warriors : The Origins of the New American Right, (Princeton, N.J.: Princeton University Press, 2001), 56.

${ }^{126}$ For another work of revisionist history see Daniel K. Williams, God's Own Party: The Making of the Christian Right, (Oxford: Oxford University Press, 2011). Williams places the origins of the political movement of the Christian Right earlier in the twentieth century and does not believe this movement was simply a response to the social changes of the 1960s and 1970s. 
neighborhoods across the country to gain funds and effectively alter the political landscape. $^{127}$

While the United States as a whole was undergoing a religious transformation, one where membership at liberal protestant churches was declining and Evangelical membership grew, Oregon too reflected these trends and Evangelical church membership grew tremendously. In the 1970 s, evangelicalism grew thirteen percent nationally and grew twenty-one percent in Oregon while mainstream church membership fell three percent nationally and grew ten percent in the state. ${ }^{128}$ The rise of evangelicals in Oregon in the 1970 s and 80 s mirrors the national phenomenon of increasing mobilization of evangelical activism. Within Oregon, “...a homogenous white population constitutes the kind of ethnic environment in which both southern-style religion and new religious movements are most likely to flourish." ${ }^{129}$ With this growth in membership we see increasingly competent grassroots efforts to pass pro-life policy.

Yet, despite the rising numbers of evangelicals and the success of pro-life conservative activists across the country, the West Coast remained a relative safe haven for abortion rights, particularly Oregon. A poll conducted by the Columbia Research Center and published by The Oregonian in 1985 showed that while the majority of Oregon residents claimed to be of a particular faith, and even identified membership in a specific local place of worship only thirty-two percent of respondents had gone to service the previous week, and forty percent of respondents felt that religion was losing

${ }^{127}$ McGirr,Suburban Warriors, 5.

${ }^{128}$ Mark A. Shibley, "Religion in Oregon: Recent Demographic Currents in the Mainstream," Pacific Northwest Quarterly, 83 no. 3, (July 1992): 84.

${ }^{129}$ Shibley, "Religion in Oregon," 86. 
importance in their lives. ${ }^{130}$ The negligible percentage of church attendance demonstrates a more nuanced interpretation of spirituality and religion. ${ }^{131}$ This is evident in the more individual or spiritual approach to religion and a lackluster Evangelical political movement in Oregon. As part of the so-called "un-churched belt" Oregon remains both open to conservative religious denominations while also maintaining its pluralistic values. These pluralistic tendencies proved to be a factor in the undoing of the pro-life agenda in the state.

After World War II the Democratic Party increasingly focused on civil rights and the interests of minority and urban populations as the Republican Party began focusing on gaining the support of socially conservative southern Democrats during the 1960s. ${ }^{132}$ After the nomination of Republican Barry Goldwater in the 1964 presidential contest, the liberal wing of the GOP would never again control the party; thus demonstrating the ideological shift to an increasingly nationalist, militaristic and later Evangelical agenda. However, fiscal or libertarian forms of conservatism have maintained power and influence. Though there are stark divides among fiscal and social conservatives, their ability to suppress more basic ideological disagreements keeps the Republican Party a viable coalition. Oregon for example, demonstrates many of these ideological splits within the Republican Party, marked by the infighting over the issue of abortion and the

\footnotetext{
${ }^{130}$ Sura Rubenstein, "Religion gains Strength, poll says," The Oregonian, December 22, 1985.

${ }^{131}$ The Oregonian, December 22, 1985.

${ }^{132}$ Darren Dochuk, From the Bible Belt to the Sun Belt: Plain Folk Religion, Grassroots Politics, and the Rise of Evangelical Conservatism, (New York: WW Norton and Company, 2011), xviii.
} 
failure to pass restrictive legislation. However Republicans in the state have found success pursuing other conservative legislation such as tax cuts.

Though nationally gaining prominence, by the 1980s religiously motivated Christian conservatives began to shift their attention and resources from the national scene to local politics. ${ }^{133}$ In hopes of better success in rural and local politics, leaders within these Christian groups researched the various avenues of legislative power. Apparently, this strategy has many faces. Minsters could encourage their congregants to support certain policy, local city council meetings would make the movement more visible, and local victories are more tangible within smaller communities. ${ }^{134}$ Notwithstanding the metropolitan Willamette Valley, Oregon's landmass is populated with small town conservatives, making the participation in conservative politics more nuanced.

Meanwhile, as more women and minorities were working to be elected into public office throughout the 1970s, activists on the grassroots level as well were influencing society. Using the Civil Rights Movement as a model, anti-war, gay and lesbian rights activists, and women's rights activists publicly demonstrated and gained attention for their various egalitarian causes. Oregon, and particularly Portland, was home to many of these socially progressive groups, which were outspoken and well organized. ${ }^{135}$ Those

${ }^{133}$ Patricia Jean Young, "Measure 9: Oregon's 1992 Anti-Gay Initiative, (master's thesis: Portland State University, 1997), 6.

${ }^{134}$ Young, "Measure 9," 6.

${ }^{135}$ Gretchen Kafoury Papers, General Politics, Box 1, Folder 1.20, Portland State University Special Collections, Portland, OR. The Women's International League for Peace and Freedom and the Oregon Council for Women's Equality were just two Oregon based groups who held rallies and informed the public about their stance against the Vietnam War 
who worked to protect women's reproductive rights and protecting abortion access took advantage of the cultural spirit of political activism. The Portland chapter of the National Organization of Women (NOW) had strong ties with many activist groups and their Bill of Rights in 1972 championed for equal and unsegregated education, maternity leave rights, the ratification of the Equal Rights Amendment, and the "right of women to control their reproductive lives." ${ }^{, 136}$ Informational pamphlets distributed by the Oregon Consumer League and the Women's International League for Peace and Freedom included hotline numbers supported by NOW supplying support for those in need of abortion, childcare, education on legislation, and employment. ${ }^{137}$ Betty Roberts, yet another outspoken supporter of women's rights was guest speaker at an event for the Jane Jefferson Democratic Women's Club of Multnomah County. ${ }^{138}$ In an era of increased political activism, there was crossover everywhere. All of these groups interacted and offered resources with one another. By supporting various group's agendas, those concerned in protecting women's access to abortion created a web of support from many different factions of the political sphere.

\section{State Funding and Abortion}

Supreme Court decisions and national pushes for regulation present opportune moments for pro-lifers to enact regulations, so too, they offer validation. Each of the four

\footnotetext{
${ }^{136}$ Gretchen Kafoury Papers, Portland NOW, Box 1, Folder 1.20, Portland State University Special Collections, Portland, OR.

${ }^{137}$ Gretchen Kafoury Papers, Portland NOW, Box 1, Folder 1.20, Portland State University Special Collections, Portland, OR.

${ }^{138}$ Gretchen Kafoury Papers, Portland NOW, Box 1, Folder 1.20, Portland State University Special Collections, Portland, OR.
} 
abortion restrictive ballot measures in Oregon have either followed or coincided with a Supreme Court decision or national amendment concerning access to abortion. Pro-life Oregonians worked in tandem with efforts within other states and took advantage of the national debate surrounding the procedure.

Figure 1. Oregon's Abortion Measures in Relation to Supreme Court Decisions

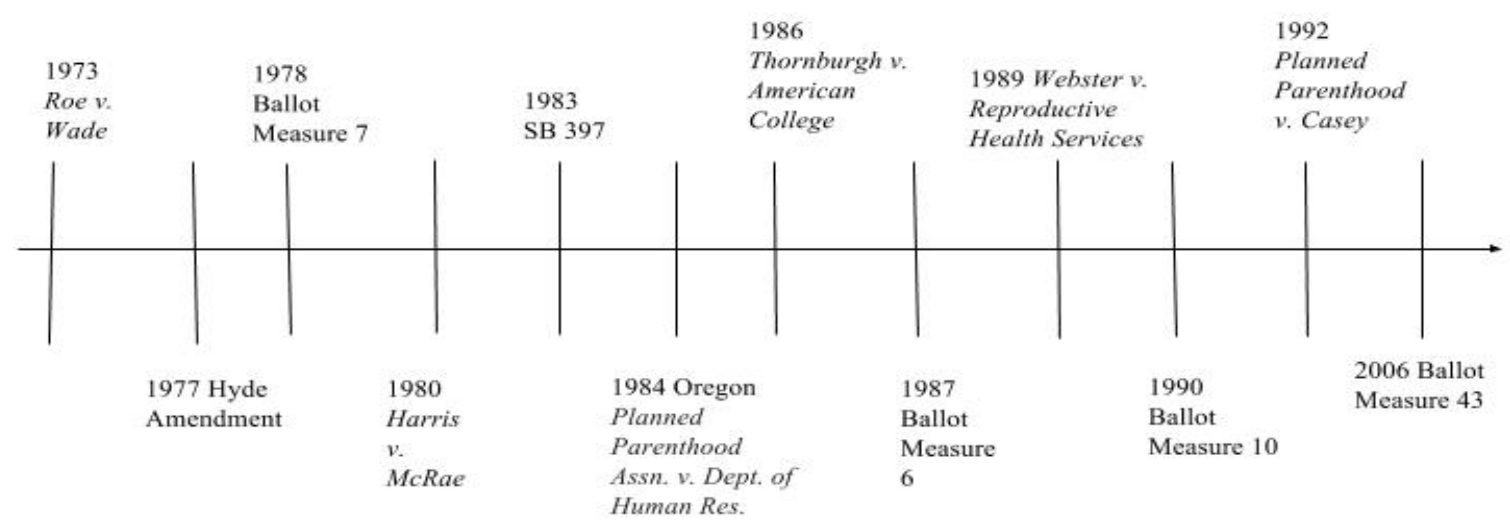

Recognizing the organized opportunity these Supreme Court decisions gave to pro-life advocates, pro-choice organizations and leaders were similarly motivated. The Oregon legislature, under Democratic Party control, actively pursued legislation extending protections for abortion, while blocking restrictive measures. Pro-choice legislators spent a tremendous amount of time tactfully preventing any restrictions on abortion from being passed. 
Lawmakers introduced forty-eight abortion-restricting bills between 1973 and 2001. Of the bills introduced, five made it out of committee to a vote; and only two came to a vote in both the Oregon house and senate. In the decade immediately following Roe, those opposed to abortion mainly focused on restricting access to the procedure by limiting public funding, a strategy that mirrors moves made by the federal government and other more abortion restrictive states at this time.

Just three years after Roe, Congressman Henry J. Hyde introduced the "Hyde Amendment" for the 1977 Medicaid appropriation. This amendment barred the use of federal Medicaid funds for abortion except if continuing the pregnancy endangered the woman's life. ${ }^{139}$ When Congressman Hyde initially introduced this amendment in a 1976 congressional session, he met opposition. Hyde argued that federal dollars should not be used to fund a questionably immoral procedure. Opposition and questions surrounding the economics of the bill were pronounced across party lines. Democratic Congressman Daniel Flood from Pennsylvania pointed to the discriminatory implications of withdrawing Medicaid funds from the procedure. "I believe it [abortion] is wrong, with a capital 'W.' It violates the most basic rights, the right of the unborn child, the right to life. ...Listen. This does not prohibit abortion," but only does so "for poor people."140 Alternatively, Oregon's Republican Senator, Robert Packwood was a staunch supporter and one of the 60 members of the senate who voted to continue Medicaid funded abortions. Eventually, the Hyde Amendment did pass and remains in effect today.

\footnotetext{
${ }^{140}$ The Abortion Rights Controversy in America: A Legal Reader, Ed: N.E.H. Hull, Williamjames Hoffer, Peter Charles Hoffer, (Chapel Hill: University of North Carolina Press, 2004), 184.
} 
Many alterations to the Hyde Amendment occurred since its inception.

Democratic presidents have reliably added reported cases of incest and rape to the list of exceptions available for accessing Medicaid funds for abortion while Republican Presidents provide exceptions to the law in situations where the woman's life is in peril. ${ }^{141}$ After the Hyde Amendment limited federal funding for abortion, often Republican led states took this opportunity to restrict legal abortion access by limiting state funding for the procedure as well.

The Court too supported the actions of these states. Two decisions, Maher v. Roe (1977) and Harris v. McRae (1980) held that neither state nor the federal governments were obligated to fund abortions for low-income women. The Supreme Court upheld the central premise of Roe; they ruled that women did in fact have the right to an abortion. However, there was no "constitutional entitlement to the financial resources to avail herself of the full range of protected choices." 142 Poor women in states with no public funding options for abortion have to personally procure the money for the expensive procedure.

Instead of immediately enacting funding restrictions in 1977 after the Hyde Amendment took effect, Oregon Governor Bob Straub called an emergency meeting where he suggested the state allocate funds for low-income Oregonians seeking abortion. Income restrictions determined who qualified to receive these allocations and placed limits on how many abortions could be performed on a particular patient. ${ }^{143}$ Though

\footnotetext{
${ }^{141}$ Rose, 130.

142 Harris v. McRae., 448 US 297 (1980).

${ }^{143}$ Ballot Measure Archive Project, series 16-23, box 6/7, Portland State University Special Collections, Portland (hereafter cited as BMAP).
} 
many Oregonians applauded Governor Straub for his proactive defense of women's rights, not everyone agreed with his actions. The aptly named Oregonians Opposed to State Financed Abortions (OOSFA) gained enough support to sponsor a ballot measure for the November 1978 state election.

Oregon's Ballot Measure 7 proposed a law that would prohibit state money from funding abortions or providing services and programs promoting abortion. ${ }^{144}$ By using examples of other states that withdrew Medicaid funding for abortions, for example, Indiana, Louisiana, Mississippi, North and South Dakota, OOSFA sought legitimacy and justification in their attempts to seek similar funding restrictions in Oregon. ${ }^{145}$ Ballot measure number 7 in the Oregon voter's pamphlet had five arguments in favor and four arguments in opposition. ${ }^{146}$ The arguments in favor attempted to appeal to fiscally concerned voters by focusing on the perceived "ignorance" and "chosen lifestyle" of the poor irresponsible women seeking an abortion. ${ }^{147}$

One argument pointed to the thousands of annual "welfare abortions" paid for by taxpayers in response to the "irresponsible sexual behavior" of the poor. While middle class white women leading the Women's Liberation Movement observed choice as essential to personal autonomy and self-determination, poor and often women of color lacked the luxury of such choice. ${ }^{148}$ National media campaigns emphasized the

\footnotetext{
144 BMAP Series 16-23, box 6/7.

${ }^{145}$ Aida Torres, Patricia Donovan, Nancy Dittes, Jacqueline Darroch Forrest, "Public Benefits and Costs of Government Funding for Abortion," Family Planning Perspectives, 18, no.3 (1986): 112.

${ }^{146}$ Official 1978 General Voters' Pamthplet, BMAP.

147 Official 1978 General Voters' Pamthplet, BMAP.

148 Sollinger, 173.
} 
"carelessness" of poor women's sexual activity and the burden it caused for taxpayers. ${ }^{149}$ Similar arguments are present in the voter's pamphlet for Ballot Measure 7.

One read, "Although our society is based on the principle that a good citizen accepts personal responsibility for his or her behavior, we are being forced to pay for irresponsible sexual behavior [regardless] of how we feel about abortion., ${ }^{150}$ Yet another argument criticizes society's assumption that everyone should "involuntarily underwrite the practice out of [their] own pockets!" "151 The focus on financial and responsibility arguments within the abortion debate is representative of the broader trend of the time that sought to monetarily restrict abortion as a means to limit access to the procedure.

On the other hand the arguments in opposition to Ballot Measure 7 highlight the necessity of the procedure. As one statement of support put it, "Access to safe and legal abortion is a necessity, not a luxury" and warned that ending this funding program would force poor women, "to seek more dangerous ILLEGAL ABORTIONS."152 Voters did ultimately defeat this measure. Following the footsteps of Governor Straub's support for Medicaid funded abortion; the public was also unwilling to withdraw state funding.

The Oregon legislature also considered similar debates surrounding abortion. In the early 1970s and 1980s, Democrats controlled both houses of the Oregon legislature. Therefor they controlled all special committees. Republican sponsored abortion restrictions were easily blocked and tabled. While other states have been more successful

\footnotetext{
${ }^{149}$ Sollinger, 194.

${ }^{150}$ BMAP Series, 44.

${ }^{151}$ BMAP Series, 44.

152 BMAP Series, 44. This argument in opposition to Ballot Measure 7 bolded "illegal abortions" presumably to emphasize their argument. Voters defeated this measure 461,542 votes to 431,577 votes.
} 
at passing such restrictions after Roe, the Oregon legislative regular sessions in the years directly after 1973 were relatively uneventful. The 1975 and 1977 regular session saw only one restriction introduced in each session.

A year after the defeat of Ballot Measure 7 pro-life lawmakers attempted to restrict abortion access by adding a parental notification provision to Oregon law. Parental notification bills are among the most popular abortion restrictions nationwide. ${ }^{153}$ Many states passed laws that required the notification of a minor's parent or guardian before physicians could perform an abortion. At the request of Right to Life Oregon, Senate Bill 818 was introduced in mid March of 1979. The bill would require minors to notify their parents of their abortions. ${ }^{154}$ Though this bill made it to a vote in the senate, it failed by four votes. This bill would have later been invalidated by the 1979 US Supreme Court decision, Belloti v. Baird II, which ruled that any notification bill had to allow for a judicial bypass option, which this Oregon bill did not.

By 1981, Oregonians elected a Republican Governor, Victor Atiyeh while the Oregon legislature remained in the control of the Democrats. Governor Atiyeh was the first Arab American governor in the United States and governed from 1979 to 1987. Governing as a Republican during the transformative years of the party displays the support of Republican policy Oregon voters held. So too, Governor Atiyeh is remembered for appointing Oregon's first female Supreme Court justice, women's rights advocate, Betty Roberts. Remember Roberts was one of the attorneys seeking to overturn Oregon's abortion ban before Roe ultimately invalidated the law. Atiyeh was also the first

\footnotetext{
${ }^{153}$ Rose, 107.

${ }^{154}$ Oregon Legislative Journal, 1979 Regular Session, Oregon State Archives, Salem, OR.
} 
governor with a female chief of staff, Gerry Thompson. ${ }^{155}$ Policy wise, Governor Atiyeh prescribed to the more fiscal conservative wing of the Republican Party, and in his appointment of Roberts to the state Supreme Court demonstrates that he did not prioritize the abortion debate in his politics.

Nationally however, the abortion policy debate took on new energy on both sides. Pro-choice activism in an era where abortion is legal, enabled activists to organize and mobilize like never before. While abortion was a crime, women had to secretly find solutions for themselves and their loved ones. Now with abortion being a widely debated legal issue, pro-choice activists were able to openly form coalitions and advocate for more access. ${ }^{156}$ Furthermore, the legalization of abortion changed the face of pro-life activism. In a landscape where laws protect the right to choose abortion, abortion providers and clinics became the new battleground for pro-life activists. ${ }^{157}$ Some pro-life groups such as Operation Rescue turned to violence and attacked abortion providers and abortion clinics. The first Planned Parenthood arson occurred in Cincinnati in 1977. In

155 Jim Moore, "Victor Atiyeh 1923-2014," Victor Atiyeh (1923-2014), Oregon Encyclopedia, accessed December 11, 2018 https://oregonencyclopedia.org/articles/atiyeh victor/\#.XBAgYZNKg1I. In keeping with his concern for fiscal stability, Governor Atiyeh is remembered for his focus on bringing international investment to Oregon. One of Oregon's worst recessions was ongoing in the 1980s, and this crisis took much of Atiyeh's attention. Atiyeh was a business owner, along with his brothers, before he was elected to public office. His financial success was part of his appeal to Oregon voters. While he did primarily focus on the Oregon economy, he took on more progressive policy agendas such as issues of land use and the environment, much like former Republican Oregon Governor Tom McCall.

${ }^{156}$ Solinger, Pregnancy and Power, 217.

${ }^{157}$ Solinger, Pregnancy and Power, 218. Solinger points out, "As long as abortion was illegal, Americans did not protest against the vast number of abortion procedures carried out in the United States each year. As long as the law defined women, with regard to pregnancy, as what philosopher Susan Bordo calls 'mere bodies,' no one picketed the offices of known abortionists, and few spoke out in the public against women seeking abortions." 
the decades that followed, dozens of arson attacks, bomb and death threats, bomb attacks, and incidents of vandalism have been reported. ${ }^{158}$

While the highly publicized debate over abortion kept the public's attention, Oregon legislators continued to contribute to the discussion. In a rare demonstration of bipartisan leadership, the Oregon senate introduced Senate Bill 363 to the 1981 regular legislative session. Again, at the request of Right to Life Oregon, SB 363 would require physicians to report any post-abortion or post-natal complications to the state health division, who would annually publish a report on the data collected. ${ }^{159}$ Though this bill did not intend to limit access to the procedure, pro-choice advocates opposed this type of legislation because these laws can promote a negative attitude towards abortion and inflate the dangers of the safe procedure. SB 363 had support across party lines and easily passed the senate after its third reading 21-9. However the bill never left the house human resources committee and died upon adjournment. ${ }^{160}$ This same year, a senate bill limiting state funding for abortion never even made it to a vote.

Figure 2: Introduced State Abortion Legislation

\begin{tabular}{|c|c|c|c|c|}
\hline \multicolumn{5}{|c|}{ Abortion Restrictions Introduced to Oregon Regular Legislative Sessions: } \\
\hline \multicolumn{5}{|c|}{ 1973-2001 } \\
\hline Year & Bill & Type Of Restriction & Vote & Outcome \\
\hline \multirow{2}{*}{1973} & HB 3282 & $\begin{array}{c}\text { Bans abortion after } 180^{\text {th }} \text { day of } \\
\text { gestation }\end{array}$ & no vote & $\begin{array}{l}\text { tabled in House } \\
\text { committee }\end{array}$ \\
\hline & HB 3292 & $\begin{array}{c}\text { Prohibition of fetal } \\
\text { experimentation }\end{array}$ & no vfote & $\begin{array}{l}\text { tabled in House } \\
\text { committee }\end{array}$ \\
\hline
\end{tabular}

${ }_{158}^{158}$ Solinger, Pregnancy and Power, 225.

159 Oregon Legislative Journal, 1981 Regular Session, Oregon State Archives, Salem, OR.

${ }^{160}$ Oregon Legislative Journal, 1981 Regular Session, Oregon State Archives, Salem, OR. 


\begin{tabular}{|c|c|c|c|c|}
\hline 1975 & SB 725 & $\begin{array}{l}\text { Redefining "human being" to } \\
\text { include certain unborn }\end{array}$ & no vote & $\begin{array}{l}\text { tabled in Senate } \\
\text { committee }\end{array}$ \\
\hline 1977 & SB 568 & $\begin{array}{l}\text { Abortion only in cases to save the } \\
\text { life of mother }\end{array}$ & no vote & $\begin{array}{l}\text { tabled in senate } \\
\text { committee }\end{array}$ \\
\hline \multirow[t]{2}{*}{1979} & SB 792 & $\begin{array}{l}\text { Prohibition on fetal or infant } \\
\text { experimentation }\end{array}$ & no vote & $\begin{array}{c}\text { tabled in senate } \\
\text { committee }\end{array}$ \\
\hline & SB 818 & Parental notification & $\begin{array}{l}\text { Senate vote: } \\
\text { failed }\end{array}$ & dies in Senate \\
\hline \multirow[t]{2}{*}{1981} & SB 363 & $\begin{array}{l}\text { Requires physician to report post- } \\
\text { abortion and post-natal } \\
\text { complications }\end{array}$ & $\begin{array}{l}\text { Senate vote: } \\
\text { Passed; no } \\
\text { vote in } \\
\text { House }\end{array}$ & $\begin{array}{l}\text { tabled in House } \\
\text { committee }\end{array}$ \\
\hline & SB 364 & $\begin{array}{l}\text { Limits funding for abortion and } \\
\text { abortion promotion }\end{array}$ & no vote & $\begin{array}{c}\text { tabled in Senate } \\
\text { committee }\end{array}$ \\
\hline 1983 & SB 565 & Parental notification & no vote & $\begin{array}{c}\text { tabled in senate } \\
\text { committee }\end{array}$ \\
\hline \multirow{5}{*}{1985} & SJR 24 & $\begin{array}{l}\text { Prohibition of state funds for } \\
\text { abortion }\end{array}$ & no vote & $\begin{array}{l}\text { tabled in Senate } \\
\text { committee }\end{array}$ \\
\hline & SB 409 & Parental notification & no vote & $\begin{array}{c}\text { tabled in senate } \\
\text { committee }\end{array}$ \\
\hline & SB 734 & Defines term: "viable birth" & no vote & $\begin{array}{c}\text { tabled in senate } \\
\text { committee }\end{array}$ \\
\hline & SB 894 & $\begin{array}{l}\text { Prohibits retaliation of healthcare } \\
\text { workers who refuse to participate } \\
\text { in abortion procedures }\end{array}$ & no vote & $\begin{array}{l}\text { tabled in Senate } \\
\text { committee }\end{array}$ \\
\hline & HB 2554 & $\begin{array}{c}\text { Prohibition of state funds for } \\
\text { abortion }\end{array}$ & no vote & $\begin{array}{c}\text { tabled in House } \\
\text { committee }\end{array}$ \\
\hline 1987 & HB 3157 & Parental notification & no vote & $\begin{array}{c}\text { tabled in House } \\
\text { committee }\end{array}$ \\
\hline \multirow{4}{*}{1989} & SB 478 & $\begin{array}{l}\text { Prohibits retaliation of healthcare } \\
\text { workers who refuse to participate } \\
\text { in abortion procedures }\end{array}$ & no vote & $\begin{array}{l}\text { tabled in Senate } \\
\text { committee }\end{array}$ \\
\hline & SB 852 & Parental notification & no vote & $\begin{array}{c}\text { tabled in senate } \\
\text { committee }\end{array}$ \\
\hline & HB 3167 & Parental notification & no vote & $\begin{array}{c}\text { tabled in House } \\
\text { committee }\end{array}$ \\
\hline & HJR 32 & $\begin{array}{l}\text { Prohibition of state funds for } \\
\text { abortion }\end{array}$ & no vote & $\begin{array}{l}\text { tabled in House } \\
\text { committee }\end{array}$ \\
\hline \multirow[t]{2}{*}{1991} & HB 3137 & $\begin{array}{l}\text { Prohibition of state funds for } \\
\text { abortion }\end{array}$ & no vote & $\begin{array}{l}\text { tabled in House } \\
\text { committee }\end{array}$ \\
\hline & HB 2219 & $\begin{array}{l}\text { Designates medical interference as } \\
\text { a crime }\end{array}$ & note vote & $\begin{array}{c}\text { tabled in House } \\
\text { committee }\end{array}$ \\
\hline \multirow{4}{*}{1993} & SB 550 & Informed consent & no vote & $\begin{array}{c}\text { tabled in Senate } \\
\text { committee }\end{array}$ \\
\hline & SB 573 & $\begin{array}{c}\text { Prohibition of state funds for } \\
\text { abortion }\end{array}$ & no vote & $\begin{array}{c}\text { tabled in Senate } \\
\text { committee }\end{array}$ \\
\hline & SB 610 & $\begin{array}{l}\text { Declared state interest in protecting } \\
\text { the unborn }\end{array}$ & no vote & $\begin{array}{c}\text { tabled in Senate } \\
\text { committee }\end{array}$ \\
\hline & SB 1034 & 24-hour waiting period & no vote & $\begin{array}{c}\text { tabled in Senate } \\
\text { committee }\end{array}$ \\
\hline 1995 & SB 803 & 24-hour waiting period & no vote & $\begin{array}{c}\text { tabled in Senate } \\
\text { committee }\end{array}$ \\
\hline
\end{tabular}




\begin{tabular}{|c|c|c|c|c|}
\hline & SB 1071 & $\begin{array}{l}\text { Prohibits the prescription of } \\
\text { RU486 (also known as the abortion } \\
\text { pill) }\end{array}$ & no vote & $\begin{array}{l}\text { tabled in Senate } \\
\text { committee }\end{array}$ \\
\hline & SB 1126 & Parental notification & $\begin{array}{l}\text { Senate vote: } \\
\text { passed; } \\
\text { House vote: } \\
\text { failed }\end{array}$ & dies in House \\
\hline & SB 2894 & Informed consent & no vote & $\begin{array}{l}\text { tabled in House } \\
\text { committee }\end{array}$ \\
\hline \multirow{5}{*}{1997} & SB 534 & Informed consent & no vote & $\begin{array}{c}\text { tabled in Senate } \\
\text { committee }\end{array}$ \\
\hline & SB 1015 & $\begin{array}{l}\text { Requires abortions to be performed } \\
\text { in ambulatory surgical center }\end{array}$ & no vote & $\begin{array}{c}\text { tabled in Senate } \\
\text { committee }\end{array}$ \\
\hline & SB 1016 & $\begin{array}{l}\text { Requires report to vital statistics on } \\
\text { abortions performed }\end{array}$ & no vote & $\begin{array}{c}\text { tabled in Senate } \\
\text { committee }\end{array}$ \\
\hline & SB 1132 & Prohibits “partial birth” abortion & no vote & $\begin{array}{c}\text { tabled in Senate } \\
\text { committee }\end{array}$ \\
\hline & SB 3532 & Parental notification & no vote & $\begin{array}{l}\text { tabled in House } \\
\text { committee }\end{array}$ \\
\hline \multirow{4}{*}{1999} & SB 603 & $\begin{array}{l}\text { Requires abortions to be performed } \\
\text { in ambulatory surgical center }\end{array}$ & no vote & $\begin{array}{l}\text { tabled in Senate } \\
\text { committee }\end{array}$ \\
\hline & SB 1330 & $\begin{array}{c}\text { Prohibition of "partial birth" } \\
\text { abortions }\end{array}$ & no vote & $\begin{array}{c}\text { tabled in Senate } \\
\text { committee }\end{array}$ \\
\hline & HB 2633 & Parental notification & $\begin{array}{l}\text { House vote: } \\
\text { passed; } \\
\text { Senate vote: } \\
\text { passed; } \\
\text { vetoed by } \\
\text { governor }\end{array}$ & $\begin{array}{l}\text { dies on governors } \\
\text { desk }\end{array}$ \\
\hline & HB 3584 & Informed consent & no vote & $\begin{array}{l}\text { tabled in Senate } \\
\text { committee }\end{array}$ \\
\hline \multirow{10}{*}{2001} & SB 228 & $\begin{array}{l}\text { Prohibition of state funds for } \\
\text { abortion }\end{array}$ & no vote & $\begin{array}{c}\text { tabled in Senate } \\
\text { committee }\end{array}$ \\
\hline & SB 750 & Prohibits "partial birth" abortions & no vote & $\begin{array}{l}\text { tabled in Senate } \\
\text { committee }\end{array}$ \\
\hline & SB 891 & $\begin{array}{l}\text { Criminalizes the unlawful handling } \\
\text { of fetal tissue }\end{array}$ & no vote & $\begin{array}{l}\text { tabled in Senate } \\
\text { committee }\end{array}$ \\
\hline & SB 974 & Informed consent & no vote & $\begin{array}{c}\text { tabled in Senate } \\
\text { committee }\end{array}$ \\
\hline & HB 2071 & Parental notification & no vote & $\begin{array}{c}\text { tabled in House } \\
\text { committee }\end{array}$ \\
\hline & HB 2769 & $\begin{array}{l}\text { Expands the definition of criminal } \\
\text { homicide to include the unborn. } \\
\text { Allows for the prosecution of } \\
\text { mother and/or physician }\end{array}$ & no vote & $\begin{array}{l}\text { tabled in House } \\
\text { committee }\end{array}$ \\
\hline & HB 3113 & $\begin{array}{l}\text { Requires abortions to be performed } \\
\text { in ambulatory surgical center }\end{array}$ & no vote & $\begin{array}{c}\text { tabled in House } \\
\text { committee }\end{array}$ \\
\hline & HB 3830 & Informed consent & no vote & $\begin{array}{c}\text { tabled in House } \\
\text { committee }\end{array}$ \\
\hline & HB 3878 & Parental notification & no vote & $\begin{array}{l}\text { tabled in House } \\
\text { committee }\end{array}$ \\
\hline & HB 3990 & $\begin{array}{l}\text { Defines "birth" for crime of } \\
\text { homicide }\end{array}$ & no vote & $\begin{array}{c}\text { tabled in House } \\
\text { committee }\end{array}$ \\
\hline
\end{tabular}




\section{A Pro-Choice Oregon Legislature}

By the 1980s nationally, many working-class American women had absolutely no public funds to access. Furthermore, many states had limited and regulated where abortions could be performed and by whom. For example, Arkansas, Idaho, and Oklahoma funded less than one-fourth of abortions for Medicaid qualified women. ${ }^{161}$ Efforts to restrict abortion became markedly more difficult ten years after Roe initially legalized abortion nationwide. In 1983, Oregon lawmakers further protected women's access to abortion by removing all pre-Roe abortion statutes from the state constitution.

Senate Bill 397, introduced by the committee on the judiciary at the request of the Women's Rights Coalition, "repeals provisions inconsistent with US Supreme Court Decisions on Abortion." ${ }^{\prime 162}$ This law made other technical changes to the state constitution by voiding all abortion restrictions from the constitution. ${ }^{163}$ Democrats 21-9 easily controlled the senate and controlled the house 36-24. After this bill passed with considerable ease, all of the state's old abortion bans had been completely removed from the state constitution. After this bill successfully passed, any new abortion statute required introduction as a constitutional amendment. Rather than simply amending laws within the constitution, amendments are a considerably more difficult political maneuver. Notwithstanding this new obstacle, pro-life conservatives would continue to introduce abortion restrictions as constitutional amendments to the state.

${ }^{161}$ Torres, Donovan, Dittes, Forrest, "Public Benefits and Costs of Government Funding for Abortion," 112.

1621983 Oregon Legislative Journal, 1983 Regular Session, Oregon State Archives, Salem, OR.

${ }^{163} 1983$ Oregon Legislative Journal, 1983 Regular Session, Oregon State Archives, Salem, OR. Multiple Women's Rights groups such as National Abortion Rights Action League (NARAL) and Planned Parenthood sponsored the removal of such language. 
Though the Supreme Court did not support mandated state funding of abortion, they consistently enfranchised the choice of women and their physicians to choose abortion, as in the decisions Planned Parenthood of Central Missouri v. Danforth (1976) and Akron v. Akron Center for Reproductive Health, Inc (1983). In Akron, the Court held that, "it remains primarily the responsibility of physician to ensure that appropriate information is conveyed to his patient, depending on her particular circumstances." This ruling held that despite the state's interest, they remained unable to impress their moral views on constituents. ${ }^{164}$ Similarly, three years later in Thornburg v. American College of Obstetricians and Gynecologists, the Court struck down all of the challenged provisions Pennsylvania had enacted such as informed consent provisions and second physicians consult mandates. Specifically designed to deter women from actively pursuing abortion, the Supreme Court interpreted these laws at an infringement of patient-doctor privacy.

Oregon invalidated a state agency rule that limited reimbursement for abortions by the state medical assistance program in 1984 . By the time the rule created by the Division of Adult and Family Services of the Human Resources Department was heard by the Oregon Supreme Court, it had already been rejected by the court of appeals for violating the equal privileges and immunities clause of the state constitution. The Oregon Supreme Court ruled that both the challenge to the agency rule and the appeal were premature. Oregon justices noted that the rule exceeded the statutory authority of the agency in the first place, the rule was invalid, and thus challenging the rule was moot. ${ }^{165}$ The Oregon Supreme Court however, did not oppose restrictions on state abortion

${ }_{164}^{164}$ Akron v. Akron Center for Reproductive Health, Inc., 462 US 416 (1983).

165 Planned Parenthood Assn v. Dept of Human Resources, 687 OR. P.2d 785 (1984). 
funding, they recognized that it would have to go through the democratic process, and not a rule of a state agency, "Only if the action was clearly so authorized is there any reason to decide whether the state or local government has adopted a policy that the constitution forbids." Furthermore, the decision left open the possibility for funding bans to move through the Oregon government, a challenge that no one has been successful in.

Later, the Oregon legislative session of 1985 saw five abortion restrictions introduced. Despite congress remaining under Democratic control, pro-life state legislators attempted to pass restrictions on state funding for abortion, parental notification laws, and statutes that would allow healthcare workers to refuse to assist women seeking abortions. ${ }^{166}$ At the request of Right to Life Oregon, lawmakers introduced a law that prohibited "retaliation against health care employees who files notice of election not to participate in termination of pregnancy." 167 Another religious lobbying group, the Oregon Association of Evangelicals, sponsored a bill that required un-emancipated minors to notify their parent or guardian. The proposed law stated that, "performing abortion in violation of provisions by maximum imprisonment of five years, maximum fined $\$ 100,000$ or both." ${ }^{, 168}$ None of these five bills reached a vote on either the house or senate floor. Furthermore, no bill received more than an initial reading. With

\footnotetext{
${ }^{166} 1985$ Oregon Legislative Journal, 1985 Regular Session, Oregon State Archives, Salem, OR. As abortion took on an increasingly partisan nature in the closing decades of the twentieth century, it can be assumed that many of these pro-life Republicans did not actually believe their anti-abortion bill would have success in a Democratic controlled legislature. The continued attempts however to introduce such restrictive legislation points to political competency, and the political wishes of lawmakers to appeal to more religious and pro-life constituents.

1671985 Oregon Legislative Journal, 1985 Regular Session, Oregon State Archives, Salem, OR.

1681985 Legislative Journal, 1985 Regular Session, Oregon State Archives, Salem, OR.
} 
pro-choice Democratic legislators controlling the Oregon legislature, tabling bills inconsistent with their agenda proved manageable.

Prominent progressive state leaders recognized that the fight to protect abortion rights could not only be within the state legislature. So too, local grassroots organizations remained engaged in order to combat pro-life policy. Women's rights activists recognized that they were not alone in their struggle against restrictive legislation. Social conservatives also targeted the gay community. ${ }^{169}$ This common fight proved beneficial in broadening and strengthening the already present coalition of socially progressive groups. Prominent women's rights advocates in Oregon politics extended their activism further than feminist issues. Leaders such as Gretchen Kafoury, Vera Katz, and Barbara Roberts were outspoken on issues surrounding housing equality, gay and lesbian rights, and racial justice. By creating allies across many social justice groups, abortion rights advocates extended their influence to more constituents.

Progressive advocacy groups often supported other liberal agendas, making the coalition of such groups more viable than religiously motivated pro-life groups, who often disagreed on other policies outside of abortion. An example of this partnership is present within Just Out, a popular gay and lesbian newspaper published and distributed in the Portland metropolitan area from 1983 to the early 2000s. The newspaper published news concerning the gay community along with announcing daily shows, events or meetings. Though Just Out primarily reported news specifically of interest to the gay and

\footnotetext{
${ }^{169}$ For the purposes of my paper, I refer multiple times to the Gay Liberation movement or the Gay Rights movement. To remain consistent with how activists of the time referred to themselves, I avoid referring to such movements anachronistically as what we would now discuss as the LGBTQ movement.
} 
lesbian community, they also printed stories concerning all progressive policy issues such as education and abortion policy.

In 1986, Just Out published an article titled, "Why Gay Men Must Vote for Abortion Rights on Ballot Measure 6." ${ }^{170}$ The article related issues surrounding the right to privacy within same sex relationships to the privacy of choosing an abortion. "A strong gay vote against the initiative could ensure the continued right of women to make their own reproductive decisions." ${ }^{171}$ The relationships formed between various egalitarian organizations proved invaluable for supporters of choice. Furthermore, this relationship proved beneficial for gay rights advocates as well and statewide anti-gay legislation failed as well in Oregon.

"Stop footing the bill for abortion!" 172 One Last Attempt at Eliminating State Funding for Abortion

Bearing in mind the politics of the decision in 1986's Thornburgh v. American College, which invalidated Pennsylvania abortion restrictions, and the recent Oregon Supreme Court order regarding state funded abortions, the decision to introduce a constitutional amendment for removing funds for abortion is questionable. However, the

${ }^{170}$ Just Out, Vol. 3, No. 12, 1986. Gay and Lesbian Periodicals Collection: Box OSA-1, Oregon Historical Society, Davies Family Research Library, Portland, OR.

${ }^{171}$ Gay and Lesbian Periodicals Collection. Box OSA-1, Oregon Historical Society, Davies Family Research Library, Portland, OR. Peggy Norman, the campaign manager working in 1994 against an anti-gay ballot measure noted how beneficial the coalition of progressive voters was in Oregon. When discussing the reactions to anti-gay ballot measures she noted, "most of them [voters] lesbian and gay, but others who are sensitive to the issues or committed to civil rights in general - all saying we don't want to do it like we did before."

${ }^{172}$ Gay and Lesbian Periodicals Collection. Box OSA-1, Oregon Historical Society, Davies Family Research Library, Portland, OR. 
Thornburg case kept the abortion debate to the forefront of American politics, a fact that pro-life conservatives capitalized upon. Pro-life activists sponsored another ballot measure that appeared in the general election of 1986. 1986's ballot Measure 6 is virtually identical to the ballot Measure 7 of 1978, yet an exception was provided in cases to save the life of the mother. ${ }^{173}$ Ballot Measure 7 proposed a constitutional amendment that would prohibit state money from being spent on abortions or providing services and programs promoting abortion. ${ }^{174}$

Pro-life advocates supporting Measure 6 were more organized than they had been eight years previously. The Committee to Stop State financed abortions began advocating for this ballot measure then later changed their name to Taxpayers for Responsible Government (TRG). TRG organized fliers and sent out letters to communities across Oregon. They received campaign donations ranging from $\$ 7.56$ to donations ranging in the multiple thousands of dollars. ${ }^{175}$ While pro-life advocates organized rallies and distributed "Yes on 6" bumper stickers and informational brochures, pro-choice activist were working feverishly to combat the notion that Measure 6 was simply a fiscal accountability measure. Concerned citizens held public community forums to voice their opinions on the proposed ballot measures. ${ }^{176}$ In a poll published on September 17, 1986, The Oregonian reported that a majority of polltakers did not support Ballot Measure 6 .

\footnotetext{
${ }^{173}$ State of Oregon General Election November 4, 1986 Voter's Pamphlet, BMAP. ${ }^{174}$ BMAP, Series 16-23, box 6/7. Because of the work done by pro-choice lawmakers, this new measure now had to be introduced as a constitutional amendment rather than an addition to an existing law. ${ }^{175}$ BMAP, Series 30-36, Box 9. 176 “Community Events,” The Oregonian, September 25, 1986.
} 
Again, arguments portraying low-income abortion seekers as irresponsible, careless, and resource draining permeated the 1986 voter's pamphlet. 1986's arguments in favor for Ballot Measure 6 were substantially lengthier than those in the previous ballot measure and they pose more figures for the voters to consider. "There are over 4,000 abortions a day in the USA...One pregnancy in every five now ends in abortion," another argument asserts, women's rights activists have noted, "abortion has simply gotten out of hand." 177 The argument sought to appeal to religious voters and asserts that they are "certainly concerned about women's rights." 178

Conversely, the 1986 voter's pamphlet had six arguments in opposition to the abortion amendment. One weakness in this proposed constitutional amendment that prochoice advocates emphasized in the voter's pamphlet was the lack of exception for access to abortion for rape or incest survivors. Due now to legal necessity, this ballot measure was posed as a constitutional amendment. A step opponents to the measure argued was “extreme," and "unnecessary." "179 Lawyers Against Ballot Measure 6 pointed to the lack of exceptions within the proposed amendment and the constitutional validity of abortion access. "Don't let the Oregon Constitution be used against women who decide to have an abortion." ${ }^{180}$ Voters voted down Ballot Measure 6. Furthermore Oregon pro-life

\footnotetext{
${ }^{177}$ State of Oregon General Election November 4, 1986 Voter's Pamphlet, BMAP. ${ }^{178}$ State of Oregon General Election November 4, 1986 Voter's Pamphlet, BMAP. As Oregon at this time had repeatedly proven to support women's rights and feminism, as proven with Oregon elected officials and policy, appealing to feminists and those concerned with gender equality seemed a targeted tactic.

${ }^{179}$ State of Oregon General Election November 4, 1986 Voter's Pamphlet, BMAP. ${ }^{180}$ State of Oregon General Election November 4, 1986 Voter's Pamphlet, BMAP.
} 
advocates witnessed defeat yet again in the 1987 regular legislative session, when only one abortion restriction was introduced. That restriction later failed. ${ }^{181}$

While Evangelical and Catholic organizations lobbied the Oregon legislature to introduce restrictions on the procedure at a local level, pro-life conservatives across the state also worked within the ballot initiative system. Fiscal conservatives favored smaller government and supported tax-limiting measures while socially conservative groups used direct democracy to attempt to limit the rights of gays and lesbians in favor of their view of traditional families. ${ }^{182}$ In the same vain of reestablishing traditional social norms social conservatives targeted abortion access. However Oregon Republicans have been less successful in voting as a block on the topic of abortion, a trend that is not seen in southern or mountain states. Based on the voting patterns of Oregonians and the constant presence of progressive legislators and leaders, social conservatives have been ineffective at selling pro-life policy to Oregonians.

Furthermore, pro-choice lawmakers added further protection for women's abortion access by removing all pre-Roe abortion statutes in the state constitution. This far, the legislative success of the Democrats occurred within a relatively friendly political climate. Democrats controlled the Oregon house, senate and governorship for much of the $1970 \mathrm{~s}$ and $80 \mathrm{~s}$, therefore, making their agenda of protecting abortion rights more straightforward. However with the election of more Republicans both locally and nationally and the rise of pro-life ideology in the Republican Party, pro-choice activists would have to change their tactics.

\footnotetext{
1811987 Oregon Legislative Journal, 1987 Regular Session, Oregon State Archives, Salem, OR.

${ }^{182}$ State of Oregon General Election November 4, 1986 Voter's Pamphlet, BMAP.
} 


\section{CHAPTER THREE \\ "Nothing in the Constitution requires States to enter or remain in the business of performing abortions." \\ The Ideological Shift of the Court and State Abortion Politics; 1989-1992}

As I have shown, the years after Roe only continued the story of women's fight for reproductive rights. The United States Supreme Court regularly visited the constitutionality of state abortion regulations in the decades following the Roe decision. While the federal government and Oregon legislature shifted to the right politically during the 1980s, grassroots organizations worked to promote family-centered ideals to the American public. So forth, many critical Supreme Court cases were decided in the 80 s and the 90s. Oregon in many aspects supported this Republican wave. Oregonians voted for President Reagan in both 1980 and 1984. In 1991 Republicans took control of the state house, the first time since Roe that the Oregon house had been controlled by Republicans. Then in 1995 Republicans controlled the state senate as well. As the country experienced this political shift, the Supreme Court decided two groundbreaking cases that changed the way states approached abortion restrictions, consequently opening the door to more restrictive state abortion policy.

Though Oregonians supported more Republican legislators and conservative policy, the majority remained unwilling to pass abortion restrictions. This chapter analyzes the attempts of pro-lifers to pass abortion restrictions during an era of Republican leadership, thus exemplifying how Oregon Republicans have differentiated themselves from lawmakers in other more pro-life conservative states. After all, the only abortion bill to pass both houses of the Republican legislature coincided with a

${ }^{183}$ Webster v. Reproductive Health Services., 492 US 490 (1989). 
Democratic governor who vetoed the bill. In not prioritizing abortion restrictions, house congressional Republicans allowed Oregon to remain protective of women's abortion access.

Furthermore, while repeated attempts in the state legislature to pass abortion legislation were thwarted, pro-life advocates on the street also worked doggedly to pass restrictions via ballot measure. Despite widespread attempts to limit abortion access during a potentially favorable political climate, these attempts failed as well. Notably, as Oregonians voted in Republican leaders, with the same stroke they voted down abortion restrictions. Thus expressing Oregon's interest in fiscal conservatism rather than sociala trend that contributes to the state's abortion policy.

Until 1989 and by consistently narrow margins, Supreme Court justices ruled that a woman's right to choose an abortion, as a constitutionally protected liberty could not be restricted by states unless clear and tailored intentions of promoting women's health could be established. Meaning, unless a state could clearly demonstrate that the imposed restriction on abortion was to promote public health, the restriction is unconstitutional. As the United States experienced a political shift to the right, the Supreme Court also shifted towards restrictive interpretations of choice within Roe. ${ }^{184}$ After Thornburgh was decided in 1986, President Reagan nominated two conservative justices to bench, Antonin Scalia and Anthony Kennedy, thus tipping the balance towards a more conservative approach to

\footnotetext{
${ }^{184}$ After the decision in Roe, often times abortion began being referred to as a "right." It is important to reinforce that there is no positive right to abortion in the United States. Though the decision in Roe has been upheld repeatedly, there remains no right to abortion. Women and physicians are free to access or provide abortions without interference from government.
} 
interpreting the constitution. This ideological shift coalesced right in time for the Court to hear Webster v. Reproductive Health Services.

The 1989 case focused on five Missouri abortion provisions of the state's 1986 act. The case challenged Missouri's declaration that life begins at conception, the forbiddance of the use of state funds for counseling women on abortion, the forbiddance of public facilities to perform abortions not necessary to save a woman's life, and the requirement that physicians perform viability tests after twenty weeks of gestation. The now conservative leaning court held that none of Missouri's provisions were unconstitutional, a ruling that broke from previous judicial precedent. Previous Supreme Court decisions were primarily concerned with protecting the private decision of women and their physicians. Now, the Court ruled that states could restrict that privacy by dictating what procedures state employees could perform. "Missouri's refusal to allow public employees to perform abortions in public hospitals leaves a pregnant woman with the same choices as if the state had chosen not to operate any public hospitals at all. The challenged provision only restricts a woman's ability to obtain an abortion to the extent she chooses to use a physician affiliated with a public hospital." ${ }^{185}$

After the Court released their decision in Webster, a July 1989 headline proclaimed, "Ruling splits Oregonians on abortion." ${ }^{\text {"186 }}$ The newspaper commissioned a poll where Oregon residents were seemingly split fairly evenly over whether or not states should be permitted to enact restrictions on abortions. The headline points to further

${ }^{185}$ Webster v. Reproductive Health Services., 492 US 490 (1989). Just as Matthews asserts the lack of a positive right to abortion, this ruling confirms that notion. So long as women had the funds, transportation, time, and competency to maneuver the healthcare field with barred access to certain facilities, they could still have access to the procedure. ${ }^{186}$ Sarah B. Ames, "Ruling splits Oregonians on abortion," The Oregonian, July 1989 
analysis and feedback of which sort of regulations Oregonians deemed acceptable or necessary, "Most Oregonians would ban abortion after the first three months of pregnancy and require parental notification for girls younger than $18 .{ }^{, 187}$ While the country reeled from the implications of Webster, Oregon leaders mobilized. Directly after Webster, The Oregonian published daily coverage on the ruling and its repercussions. ${ }^{188}$

This decision only served to provoke Oregon abortion rights activists. Former Oregon Supreme Court Justice Roberts launched the "Gear Up" campaign in 1989 to focus on educating the public on both the reproductive rights of women and the effects that the Supreme Court ruling had on these rights. Roberts also sent out various memos after Webster:

Do not be fooled by the language of the majority of the United States Supreme Court. As Justice Blackmun said, their language is deceptive and callous. The majority says Roe is undisturbed. That is deception. We know, in fact, that Roe no longer exists as we have known it. ${ }^{189}$

Roe had in fact been upheld and ultimately, abortion was still constitutionally legal. Yet the restrictions affirmed in Webster narrowed the options available to women due to now constitutional state regulations. Roberts sought to instill in state lawmakers and the public the crumbling state of women's rights. State legislatures were now a "battlefield for a woman's right to choose." 190

This battlefield that Roberts discussed to the Oregon public did not go unnoticed to the Evangelical pro-lifers within the Oregon Citizens' Alliance. The OCA used their expertise in fundraising and networking to advocate and sponsor Oregon legislation to

${ }^{187}$ Ames, "Ruling splits Oregonians on abortion".

${ }^{188}$ Issues, Betty Roberts Papers, Portland State University Special Collections, Portland. ${ }^{189}$ Issues, Betty Roberts Papers, Portland State University Special Collections, Portland. ${ }^{190}$ Issues, Betty Roberts Papers, Portland State University Special Collections, Portland. 
reflect their own socially conservative viewpoint. The OCA preamble stated, “...today, the principles upon which this great and good republic rests are under determined attack." 191 The attack which the OCA refers to is the threat recognized by the Christian Right, that of feminism, abortion, and homosexuality. The statement of principles goes on to oppose homosexual individuals and their demand for equal rights, and further affirms that "life is a gift from God...[and] abortion and euthanasia are a denial of humanity and human dignity, and must be prohibited by law."192 In order to accomplish their socially conservative goals, the OCA employed both their massive resources and expertise on influencing government.

The OCA had a complex mailing list that created a broad network for funding. From single digit dollar amounts to donations in the tens of thousands of dollars, the OCA managed to reach many regions of the state with their influence, even outlining in their donation letters with directions on how to easily file a political tax credit. ${ }^{193}$ Using popular conservative rhetoric to appeal to concerned Oregonians already shifting to support more conservative leaders, these letters urged citizens to donate in order to combat liberal ideologies. Ideologies that according to the OCA held "that homosexual behavior, even man-boy sexual relationships are normal, [and] that brutal dismembering of an unborn child within the very womb of its mother is a right to privacy." ${ }^{\prime 194}$ Also

\footnotetext{
${ }^{191}$ Oregon Citizens Alliance Information Pamphlet, Charles Hinkle Collection, box 5, folder 10, Oregon Historical Society, Davies Family Research Library, Portland, OR. 192 Oregon Citizens Alliance Information Pamphlet, Charles Hinkle Collection, box 5, folder 10, Oregon Historical Society, Davies Family Research Library, Portland, OR. ${ }^{193}$ Oregon Citizens Alliance Informational Pamphlet, Charles Hinkle Collection, box 5, folder 1, Oregon Historical Society, Davies Family Research Library, Portland, OR. ${ }^{194}$ Queer Nation Portland Collection, box 2, folder 4, Oregon Historical Society, Davies Family Research Library, Portland, OR.
} 
furthering the OCA's command of the public's attention were expensive investments in radio and television advertisements. For example, one radio add had a small foster child asking, "Where's my mommy?" after being adopted into a household with two fathers. ${ }^{195}$ Radio advertisements like this enforced the OCA's commitment to the "traditional" family, one with one father and one mother. This ad highlights the OCA's opposition to same-sex couples raising children.

Hundreds of OCA members knocked on doors and posted in front of shopping centers to gain signatures to introduce ballot measures. Rallies drew crowds to hear enthusiastic characters such as the former leader, Lon Mabon speak on issues central to the Evangelical agenda. This active mobilization proved successful in more rural districts of Oregon. The OCA did not just focus on one region; they introduced measures in districts across Oregon all at once. In a January 1992 press statement, the OCA announced they were filing thirty-two country and city initiatives. "It is our plan, taking the present weather conditions into consideration, to file these local initiatives over the course of the next three or four working days. ${ }^{, 196}$ Hoping to capitalize on the current "weather conditions" of national Christian conservative success, the OCA sponsored antigay and anti-abortion ballot initiatives across Oregon.

Arguably, it was recognized that not all of these initiatives would be successful, yet they did succeed in gaining recognition for the group's agenda. In 1993, voters in six Oregon cities ultimately passed anti-gay rights measures. One such measure allowed discrimination based on orientation in hiring practices, though ultimately a house bill

${ }^{195}$ Charles Hinkle Collection, box 5, folder 10, Oregon Historical Society, Davies Family Research Library, Portland, OR.

${ }^{196}$ Charles Hinkle Collection, box 5, folder 2, Oregon Historical Society, Portland, OR. 
overturned these statutes. Responding to the group's success, Mabon stated, “I think the citizens are just saying 'no'.," 197 The OCA targeted middle of the road voters not entrenched in a political party previously. During the Republican takeover of the late 1980s and 1990s the OCA was able to gain momentum and success in their pursuit of moral legislation in Oregon.

While legislation seeking to limit social equality and abortion access waivered, other stereotypically conservative legislation had more success in Oregon. Prior to 1990, Oregonians rejected nineteen tax or school financing initiatives. ${ }^{198}$ Following the national trend of tax revolts sparked by California's 1978 Proposition 13, fiscally concerned conservative activists successfully sponsored Measure 5 for the 1990 general election. Spurred by anxiety over the cost of property taxes and a rising distrust of government spending, activists across the country sponsored similar tax-cutting bills. Emboldened by Reagan-era economic rhetoric, which favored a laissez-faire approach to economic regulation, fiscal conservatives organized Oregonians to pass Measure 5, thereby amending the state's constitution to cap property taxes, restrict tax increases for two years, and require a mandatory two-thirds legislative vote for any new taxes. ${ }^{199}$ Tax reform and anti-abortion legislation are both characteristic of Republican ideology. The success of one policy over the other in Oregon outlines a particular type of conservatism present in Oregon. Arguably, Oregon conservatives are concerned more with economic and fiscal matters rather than social issues, particularly abortion rights.

${ }^{197}$ Discrimination Pacific Northwest, vertical File, Politics and Miscellaneous Collection, Oregon Historical Society, Davies Family Research Library, Portland, OR.

${ }^{198}$ Beth Cookler, "The Impact of the Tax Revolt and School Reform on Oregon Schools during the 1990's," (master's thesis: Portland State University, 2014), 14.

${ }^{199}$ Cookler, "The Impact of the Tax Revolt," 13. 
Figure 3. Index for Ballot Measure Initiatives in Oregon Elections

\section{Abortion Restrictions Introduced to an Oregon General Election via Ballot Measure}

\section{General Election \\ Year}

1978

1986

1990

2006

\section{Ballot}

Measure

Ballot

Measure 7

Ballot

Measure 6

Ballot

Measure 10

Ballot

Measure 43

\section{Description}

A law to prohibit state money from funding abortion or programs that promote abortion except when necessary to save the life of the mother abortions or programs that promote abortion

Would require doctors to notify a parent, guardian, or agency of care two days before performing an abortion on a minor

Would require doctors to provide 48 -hour notice to un-emancipated minor's parent or guardian before an abortion is performed

The OCA and Abortion Policy

Perhaps the most intriguing abortion ballot measure to fail was 1990's ballot Measure 10. The OCA took up the pro-life cause by rallying for this measure. Directly after the Webster decision upheld state abortion restrictions presented an ideal time for states to enact restrictions of their own. Oregon's Ballot Measure 10 proposed that a: 
Doctor must give notice at least two days before minor's abortion. Notice goes to parent picked by minor or parent with custody. If no parent, notice goes to adult or agency caring for minor. Doctor may delay notice if doctor believes minor will die or suffer major physical harm. Notice excused if minor is victim of reported abuse at home or reported rape causing pregnancy. Minor and parent may sue doctor for inadequate notice. Doctors cannot insure against this lawsuit. Doctor may have license suspended. ${ }^{200}$

Instead of focusing on the financial aspect of abortion like previous ballot measures had sought to do the OCA condemned the morality of abortion and as their statement of principles suggests, they sought to create laws that would restrict the procedure. If the voter were to tally the arguments for and against the measure, they would easily see that the arguments in favor for the measure outnumbered those against. The pro-life movement was not going to be outnumbered in the voter's pamphlet as they had been in the 1986 election. Fifteen of the twenty-four arguments were in favor of the ballot measure. $^{201}$

Similar to the previous abortion ballot measures, pro-life advocates sought justification by listing other states that had already passed similar legislation. "In Minnesota, after parental involvement laws were passed, teen pregnancy dropped 32\%, teen abortions dropped 40\%, and teen births dropped 23\%... and in Missouri, teen pregnancies dropped 9.7\%, and teen abortions dropped $27.5 \% .^{202}$ Also, the story of

2001990 Voters' Pamphlet. State of Oregon General Election, 84, Oregon Historical Society, Davies Family Research Library Portland, OR.

${ }^{201} 1990$ Voters' Pamphlet. State of Oregon General Election, 84, Oregon Historical Society, Davies Family Research Library Portland, OR. 2021990 Voters' Pamphlet. State of Oregon General Election, 84, Oregon Historical Society, Davies Family Research Library Portland, OR. This argument further asserts that in states where parental consent is required teenagers are more cautious about the consequences of their sexual activity. 
Becky Bell provided a heartbreaking story for pro-lifers to exploit. In 1990, the infamous story of pregnant seventeen-year-old Becky Bell became well known.

Bell did not want to inform her parents of her pregnancy. The story goes that rather than comply with her state's parental consent law, she sought an illegal abortion and later died from an infection stemming from the procedure. ${ }^{203}$ Pro-lifers used this horror story to enforce the importance of parental involvement in a minor's pregnancy decision. "The real message of Becky Bell's death is that parental involvement laws can help prevent tragedies such as this. ${ }^{, 204}$ This common thread of engaging a parent's natural concern for their children permeates the entire pamphlet.

On the other hand, arguments in opposition of Measure 10 used these tragic stories to emphasize the dangers of parental consent laws. The "NO on 8 and 10" campaign presented the dangers of parental notice laws. They asserted that Oregon teenagers had died from "back-alley abortions" and pointed to the risks presented to young women in vulnerable home situations. ${ }^{205}$ Another argument presented the

${ }^{203}$ Rose, 107. Rose analyzes the Becky Bell story in her book in depth. Each side of the abortion debate interpreted her story differently and used her sad situation to strengthen their argument.

2041990 Voters' Pamphlet. State of Oregon General Election, Oregon Historical Society, Davies Family Research Library, Portland, OR. Interestingly on argument on page 88 of the voter's pamphlet explains that there is confusion surrounding the actual cause of death of Ms. Bell. The germ that killed her was "unlikely to originate from a contaminated abortion procedure." The cause of death was undetermined and septic abortion was not substantiated within the argument. While this argument was used to support parental abortion notification laws, there is not evidence that Ms. Bell ever had an abortion, only that she had considered one. While this argument establishes the mysterious circumstances surrounding Ms. Bell's death, United Families of Oregon, who funded this argument is adamant when they asserted, "The real message of Becky Bell's death is that parental involvement laws can help prevent tragedies such as this."

${ }^{205} 1990$ Voters' Pamphlet. State of Oregon General Election, Oregon Historical Society, Davies Family Research Library Portland, OR. 
possibility of parental notification laws causing violence towards young women seeking medical care; and called the bill a "death warrant."206

Additionally, the Oregon Republican Coalition for Choice (ORCC) funded an argument in opposition to the measure. ${ }^{207}$ As Republicans in the state legislature remained blasé on the issue of abortion and did not prioritize votes on any legislative measures, this coalition of Republican voters openly opposed any abortion restrictions. The coalition referred to arguments of privacy, resource management, and inference with doctor patient privilege. ${ }^{208}$ The ORCC asserted:

Measure 10 does not offer any real or compassionate protection for teenagers who cannot talk to their parents or are victims of abuse. The measure offers no opportunity for Court intervention, so the only remaining options would be an unwanted pregnancy or a back-alley abortion. ${ }^{209}$

The safety of young women played a large role in the tactics pursued by the campaigns against a parental notification measure. Similar to how the Oregon legislature debated

${ }^{206} 1990$ Voters' Pamphlet. State of Oregon General Election, Oregon Historical Society, Davies Family Research Library Portland, OR. Sponsored by the American Civil Liberties Union of Oregon, this argument enforces the "cold" nature of the bill and asks voters to have compassion for women in less than fortunate situations.

${ }^{207} 1990$ Voters' Pamphlet. State of Oregon General Election, Oregon Historical Society, Davies Family Research Library, Portland, OR.

${ }^{208} 1990$ Voters' Pamphlet. State of Oregon General Election, Oregon Historical Society, Davies Family Research Library, Portland, OR.

${ }^{209} 1990$ Voters' Pamphlet. State of Oregon General Election, Oregon Historical Society, Davies Family Research Library, Portland, OR. This argument further points to Oregon's history of being supportive of abortion rights and choice. Pro-choice Republicans in this election seem to have been aware of the pro-choice leanings of the state and wanted to maintain that reputation. Furthermore, throughout all of the arguments opposing this ballot measure are arguments pointing to the humanity of women seeking abortion services and how immoral this law would be. Ballot Measure 10 failed with over $52 \%$ of the population voting against the measure. "Oregon Notice to Minor's Parents Before Abortion: Ballot Measure 10" Ballotpedia, accessed December 11, 2018. https://ballotpedia.org/Oregon_Notice_to_Minor\%E2\%80\%99s_Parents_Before_an_Abo rtion,_Measure_10_(1990) 
issues of family communication in their refusal to pass abortion restrictions, the Oregon voter considered this reality as well. Because of campaigns such as the No on 8 and 10 Campaign, NARAL, the ACLU, and prominent political figures speaking in defense of reproductive freedom, Oregon voters defeated 1990's parental notification ballot measure. Regardless of the Webster decision and the extreme organization and influence of the OCA this ballot measure failed.

While Oregon grappled with its own internal policy debates over abortion, the rest of the country too faced these questions over the procedure. Outside of Oregon, in more religiously conservative states, abortion restrictions had an easier time passing. In so doing, pro-choice activists then pushed to challenge these restrictions. In 1992, after two more conservative Supreme Court justice appointments by President George H.W. Bush; David Souter and Clarence Thomas, the conservative court heard arguments in Planned Parenthood of Southeastern Pennsylvania v. Casey.

Pennsylvania had amended their constitution in 1988/89 to provide further regulations on women seeking abortion. An informed consent provision, 24 hour waiting period, parental and husband notification, and building regulations were a few of the clauses in the amendments. ${ }^{210}$ Casey is important in American abortion politics because it established the doctrine of "undue burden" for women seeking abortion. Though, Roe was ultimately upheld and the constitutional right for women to choose abortion remains in place, the reality of choice for many women is ambiguous.

${ }^{210}$ Planned Parenthood of Southeastern Pennsylvania Et Al v. Casey Et Al., 505 US 833 (1992). 
The only Pennsylvania statute invalidated in this decision was the husband notification statute. "It is an inescapable biological fact that state regulation with respect to the child a woman is carrying will have a far greater impact on the mother's liberty than the father's." ${ }^{211}$ The focus on biology rather than the western familial unit is inescapable. Previous decisions, such as Bradwell v. Illinois clearly outlined the expectations of women in society as a singular entity under her husband. Under this rationale, a husband could reasonably be in charge of all family decisions, including whether or not his wife gave birth. However the Court chose instead to focus on a more modern view of women's autonomy. "The Pennsylvania abortion law embodies a view of marriage consonant with the common-law status of married women but repugnant to our present understanding of marriage and of the nature of the right secured by the Constitution." 212

On the other hand, mandatory waiting periods and parental consent legislation were upheld, so states now had with even more opportunity to regulate abortion after the Casey decision. Justice O'Conner held, “Though the woman has a right to choose to terminate or continue her pregnancy before viability, it does not at all follow that the State is prohibited from taking steps to ensure that this choice is thoughtful and informed." ${ }^{213}$ Remember, Justice O'Conner sided with the minority in the Akron and Thornburgh decisions that had overturned state ordinances restricting abortion access in

${ }^{211}$ Planned Parenthood of Southeastern Pennsylvania Et Al v. Casey Et Al., 505 US 833 (1992).

212 Planned Parenthood of Southeastern Pennsylvania Et Al v. Casey Et Al., 505 US 833 (1992).

${ }^{213}$ Planned Parenthood of Southeastern Pennsylvania Et Al v. Casey Et Al., 505 US 833 (1992). 
1983 and 1986. O'Conner had long believed that such provisions did not disrupt the central premise of Roe, though now she had the majority behind her.

This doctrine continues to be tested. The shifting intricacies of what can constitute "undue" across state, class, and racial lines are central to the political argument. Justice Roberts announced her concern for the future of women's reproductive freedom directly after the Casey decision:

I am disappointed that the highest court in our country has taken away a right that will cause panic and pain for thousands and thousands of women. And I am angry that the President of the United States deliberately set up the Court for that purpose. I am angry that the President believes he can pay his political dues to the Radical Right in our Society with the agony and suffering of women. ${ }^{214}$

The voting patterns of Oregonians display a similar prioritization of values to Justice Roberts. The belief that restrictions on abortion do in fact impose an undue burden on women's autonomy and safety is evident among the state legislature since every abortion restriction was repeatedly blocked or voted down. Despite the Republican leanings of the Oregon legislature throughout the 1990s, discussion, advocacy, and sheer political maneuverings kept the state free from any abortion restrictions.

\section{The Oregon Legislature after Planned Parenthood v. Casey}

In a span of nineteen years, the Supreme Court had gone from promoting the protection of women's private medical decisions to the allowance of state regulations informing women's decisions. While many states across the country used the Court's approval of such regulations to enact restrictive legislation, Republican Oregon lawmakers struggled to make that a reality in their home state. No abortion bill made it

${ }^{214}$ Issues, Betty Roberts Papers, Portland State University Special Collections, Portland. 
through both houses of the Oregon legislature until 1999. The 1993, 1995, and 1997 regular legislative sessions collectively saw thirteen restrictions introduced. Despite considerable Republican majorities, not one of these abortion provisions made it to the governor's desk. Most bills in fact remained in committee and didn't reach a vote at all. When Democrats controlled the state legislature, tabling abortion restrictions fit into their party's ideological agenda that supported abortion access. However the Republican controlled legislature doing the same reflects an unwillingness of Oregon Republicans to prioritize abortion restrictions despite the national party's commitment to the pro-life movement.

1995 's Senate Bill 1126 was a bill to actually make it to a vote; yet while it passed the senate it failed in the Oregon House of Representatives. Introduced at the request of Right to Life Oregon, the bill required, "that parent, guardian or conservator of minor female be notified before abortion performed. ${ }^{215}$ Though Republicans held majorities in both houses of congress, pro-life lawmakers were unable to muster the votes. Republican State Representative Lynn Lundquist voted against her own party's bill and provided explanation for doing so.

On May 22 along with many of my colleagues, both Republican and Democrat, I cast the most difficult vote of my political career...As a parent, I would want my daughter to come to me during this crisis in her life. However, I would want her to share this with me because she believed that is the best alternative, not because it is the law... I have had many calls and letters from constituents on both sides of this issue. I appreciate the views and input-their deep feelings are unmistakable. After much deliberation on the tremendous potential danger to Oregon teenagers, and adhering to my strong belief that you cannot legislate morality or parentdaughter relationships, I voted no on Senate Bill $1126 .{ }^{216}$

${ }^{215} 1995$ Legislative Journal, 1995 Regular Session, Oregon State Archives, Salem, OR. ${ }^{216} 1999$ Legislative Journal, 1999 Regular Session, Oregon State Archives, Salem, OR. State Representative Lundquist went on to say, "I know what it is to search three states 
Arguably, since the bill failed to reach a majority vote, more of Lundquist's Republican colleagues felt similarly to her, that Christian morality could not be legislated. While Oregon voters and legislators proved willing to vote for Republican leaders, they favored conservative policy that addressed the economy rather than society.

However the failure of all previous bills did not dissuade Oregon pro-life conservatives. 1999 was a particularly active year for the introduction of restrictive bills to the Oregon legislature. A Republican controlled legislature introduced five abortion restrictions throughout the 1999 regular session. These bills focused on informed consent, funding, and parental notification. In a more Catholic tradition of pro-life advocacy, Oregon's "death with dignity" act was targeted in this session as well, though similar to other religiously motivated laws, the bill was unsuccessful. ${ }^{217}$

1999’s House Bill 2633 was a parental notification bill. Some Democrats were in support of parental notification laws. Democratic Representative Kurt Schrader stated that he supported the first version of the bill, which allowed for a judicial bypass version for young people in abusive situations. However he clarified:

The second version of House Bill 2633 did not protect children from abusive, negligent or violent parents. I found in my '97 session service on the Children and Families Committee, that an astonishing number of children don't have parentseither physically or emotionally... This bill does not provide safe parental

for a daughter that ran away because she knew our family values and was ashamed of what she and her boyfriend had done in our home. The love we shared was somehow not adequate to overcome her emotionally charged decision to run," exemplifying the truly personal influence this bill had on her. In sticking with the libertarian wing of the Republican Party, many Republicans were unwilling to vote for a bill that attempted to legislate family relationships.

${ }^{217} 1999$ Legislative Journal, 1999 Regular Session, Oregon State Archives, Salem, OR. 
notification as the backers had originally sought... This is why I supported the first version, not the current bill, which is an inadequate and illegal alternative. ${ }^{218}$

Another state Democrat also explained why they voted against this bill:

Under current law, a person 15 years of age or older can consent to major medical procedures without any notice or consent of a parent or guardian. Why should we create an exception for one procedure, an abortion that by its very nature pertains only to young women? Are we sending the message that young women are incapable of making medical decisions by themselves while no such limitations are placed on their young male counterparts? ${ }^{219}$

HB 2633 is the only abortion bill to ever pass both houses of the Oregon legislature.

While this may have finally felt like a win for pro-life conservatives in the state, it was for not, and Democratic Governor John Kitzhaber vetoed the bill. Arguably, timing to an extent explains how and why Oregon has remained free from abortion restrictions. While it is true that Oregon has long stoked the flames of feminist leadership and Republicans within the state are hesitant to prioritize abortion legislation, no abortion bills ever made it to a Republican governor's desk. Furthermore, by the time an abortion bill did make it out of the state legislature, Oregonians had elected a pro-choice governor who killed the bill.

Where religiously motivated conservatives have been unsuccessful in Oregon, elsewhere across the country pro-life activists have been able to sway the vote more starkly. Between 1992 and 2000, Alabama's lost eight of its eighteen abortion providers for the state, leaving eighty-seven percent of counties without access to services. ${ }^{220}$ As pro-life activists claimed victories across the country, the absence of any restrictions in Oregon became starker, especially after the defeat of 2006's Ballot Measure 43.

2181999 Legislative Journal, 1999 Regular Session, Oregon State Archives, Salem, OR. 2191999 Legislative Journal, 1999 Regular Session, Oregon State Archives, Salem, OR. ${ }^{220}$ Rose, 92. 
Measure 43 of the 2006 general election would have required a forty-eight-hour notice to an un-emancipated minor's parents before said minor could pursue an abortion, was defeated. ${ }^{221}$ The availability of media and the Internet played to the advantage of organizations. Multiple newspapers and media outlets printed editorials in opposition to Ballot Measure 43. The Hood River News published an argument in opposition to the measure stating Measure 43 was just a "solution waiting for a problem," and that in fact, teen pregnancy and abortion rates had been falling since the 1990s, and to regulate the procedure was irrational and unnecessary. ${ }^{222}$ Contributions received by the "NO on 43 Committee" were used on web design and research. ${ }^{223}$ Media proved to be vital for prolife campaigns attempting to reach a broader set of voters.

The arguments in the 2006 Oregon general election echoed those stated in the political debates that had previously permeated Oregon media. By comparing the sheer amount of arguments within the voter's pamphlets we witnessed the evolution of ballot measures in Oregon. Measure 43 had thirty-three arguments in favor and twenty-four arguments in opposition in the pamphlet. ${ }^{224}$ Each side of the abortion debate noticed the importance of printed arguments for Oregon voter's who are not familiar with the debate. The arguments in favor followed a similar strategy to the previous ballot measures in providing a mix between personal testimonies, moral arguments and claims to legitimacy

${ }^{221}$ BMAP, box 97 , folders $110-111$. The summary of the initiative held that the law would provide exceptions to written notice in cases of medical emergencies but such emergencies did not included rape or incest. Minors could request an administrative law hearing to request abortions without notifying their parents or guardians. Physicians could be prosecuted under this law for failure to comply.

${ }^{222}$ BMAP, box 97, folder 110 .

${ }^{223}$ BMAP, box 97 , folders $110-111$.

${ }^{224}$ BMAP, box 97 , folders $110-111$. 
based on other states' laws. A young woman claimed she was pressured into having an abortion from her irresponsible boyfriend and states, "My boyfriend left me, but my parents stayed."225 Another argument in the pamphlet capitalizing on increasingly religious opinions over abortion quotes Genesis, Job, and Psalms to display a religious and moral opposition to abortion in hopes to appeal to religious voters. ${ }^{226}$ Similar to previous ballot measures, attention was given to the rights of the parents. An argument proclaims, "Moms and dads are responsible for their children's well-being, and Measure 43 allows a parent to be aware and involved in a difficult situation in her daughter's life." This tactic was present in the prior parental notification initiative as well.

One argument that particularly pointed to the massive opposition to Ballot Measure 43 was an argument presented by M. Hoeven and the No on Measure 43 Campaign. This argument simply presented a long list of community organizers and committees who opposed the measure. Included were Mayor Tom Potter, Governor Barbara Roberts, The Oregon Medical Association, and retired Police Lieutenant Jeff Barker. ${ }^{227}$ Reverends were listed as well as sexual assault clinics. This simple list spoke volumes to the voter to establish how prominent Oregonians were unwaveringly prochoice.

These aforementioned ballot measures provide a tangible representation of ideas held by both sides of the abortion controversy in Oregon. Examining the stories, numbers, and facts advocates decide to share, or the arguments put forth by activists

${ }^{225}$ BMAP, box 97 , folders $110-111$.

${ }^{226}$ BMAP, box 97 , folders 110-111.

${ }^{227}$ BMAP, box 97 , folders $110-111$. 
within these pamphlets unveil the larger political debate and conversation present in each year since Roe. Early ballot measures chose to highlight the fiscal aspect of the funding of abortion while later ballot measures focused on a Christian sense of morality. Bearing in mind that many voters do not participate in community events or rallies concerning every ballot measure, arguments within voter's pamphlets proved important in swaying public votes. In many cases, ballot measure arguments are the only interaction voters have with election issues. How an individual votes can ultimately depend on which side of the debate presents a stronger argument. The dynamic arguments within voter's pamphlets facilitated these ballot measures' defeat.

There is not a single reason why Oregon has remained free from such restrictions. As Oregon elected a more conservatives in the 1980s and 90s, abortion rights still remained in tact. Republican controlled committees repeatedly tabled abortion laws in favor for fiscal agendas. The last Republican governor to be elected in Oregon was Victor Atiyeh, who left office in 1987. During his time in office, Democrats controlled both houses of government, and he never saw an abortion bill on his desk, furthermore, he nominated a pro-choice advocate to the state supreme court. Since then, Oregonians have consistently elected Democratic governors overwhelmingly in support of abortion rights and who would veto any abortion restrictive bill. Despite Republican control of the legislature, they have been only able to muster the votes for one abortion bill to pass the legislature in the decades after Roe, which was later vetoed by a Democratic governor.

While Oregon does mirror national politics in its attempts to push anti-abortion legislation, the politics and legislature remain unique to the rest of the country. It is evident that this narrow interpretation of Christian society was unpopular in both the state 
legislature and amongst voters when we analyze the voting pattern of Oregonians. The legislative history of Oregon presents a window into broader American politics. The United States as a whole underwent a shift as socially conservative activism found a mainstream voice within the Republican Party and that activism is present and organized in Oregon. However the flexibility of Oregon Republicans is clear in their unwillingness to prioritize any abortion legislation, a fact that differentiates them from others across the country in the same political party. 


\section{CONCLUSION}

As my research has shown, up until abortion was legalized nationwide, Oregon mirrored American abortion policy writ large, by outlawing the procedure in the midnineteenth century. These abortion laws were difficult to enforce, and women's rights advocates worked to invalidate and liberalize state laws even before Roe was decided. Because of difficulties in prosecution and executives unwilling to enforce the ban, few in Oregon history were ever convicted for breaking the abortion ban and many providers performed abortions openly. Furthermore, even during a time when abortion was illegal, women's rights advocates worked to ensure that women from all socioeconomic backgrounds had access to contraception, an ideology that was not popular until the late twentieth century. Though Oregon criminalized abortion similar to the rest of the country, roots of pro-choice ideology and women's reproductive freedom advocacy were set long before Roe was decided. ${ }^{228}$

Just as religious conservatives gained a national platform within the Republican Party after Roe, pro-life lawmakers in Oregon attempted time and time again to pass legislation restricting abortion access. When the United States as a whole shifted to the right politically, Oregon lawmakers supportive of abortion rights and blocked abortion bills within the legislature. Moreover fellow Republican lawmakers were not particularly concerned with abortion legislation. The voting record of the Oregon legislature proves

${ }^{228}$ This trend has continued. In August of 2017, Governor Kate Brown signed into legislation, The Reproductive Health Equity Act; thus requiring insurers to cover birth control and abortions at no cost to the patient. This law also covers patients regardless of gender, gender identity, or immigration status. This move is seen as a scramble to ensure state reproductive justice under a federal administration that prescribes to the pro-life wing of the Republican Party. See Susan Milligan, "Oregon Passes Law Protecting Abortion Rights," U.S. and World News, August 15, 2017. 
Republicans were more concerned with fiscal matters, rather than social. Out of the dozens of abortion bills that were introduced to the Oregon legislature in the thirty years following Roe, only one passed both houses, only to later be vetoed by the Democratic Governor. The years since Roe have exposed an intricate relationship between states rights and the federal government. States governments continue to push the boundaries of the ruling. ${ }^{229}$ On multiple occasions plaintiffs asked the Supreme Court to review restrictive legislation, and the Court has repeatedly upheld state restrictions.

Still, Oregon participates in the national discourse concerning abortion access, and abortion restrictions are regularly introduced to the state legislature and through ballot initiative. However voters remain supportive of abortion rights. If this political discourse reveals anything, it is that Roe is far from the decisive moment in American history that many interpret it to be. Yes, Roe v. Wade legalized abortion in the United States, but the years since the decision are peppered with legal disputes and political debate that continually test women's right to access safe and legal abortion. Oregon has long participated in the national legal discourse surrounding contraception and abortion and Oregonians on both sides of the isle continue to voice their pro-choice leanings. ${ }^{230}$

${ }^{229}$ In early 2018, Mississippi began banning all abortions after fifteen weeks of gestation. On May 4, 2018 Iowa Governor Kim Reynolds signed into law a "fetal heartbeat" restriction, a ban that would prohibit most abortions after about six weeks of gestation. A federal court later placed this restriction under a temporary injunction. ${ }^{229}$ In June of 2018 the United States Supreme Court overturned a California state law that mandated socalled "women's crisis pregnancy centers" to disclose if they do not have any medical professionals working on site and inform their pregnant patients of state funded options including abortion that are available to them. See Bill Cheppell, "Judge Temporarily Blocks Iowa's 'Fetal Heartbeat' Abortion Law,” NPR, June 1, 2018.

${ }^{230}$ While the national Republican Party has maintained its commitment to the pro-life movement, Oregon Republicans remain indifferent to or even supportive of abortion rights. The 2018 Republican candidate for Governor, Knute Buehler is pro-choice. His 
What makes Oregon unique in this sense is acknowledging that not only was Oregon one of the first states to liberalize their abortion law prior to Roe, but it never adopted a single restriction after the 1973 decision. Proactive government leadership, community activism, and prominent political figures rallied behind women's rights and championed successfully for the protection of this constitutional right. So long as abortion remains a topic of contention in American policy, Oregon will likely remain at the forefront of the debate.

campaign website asserts, "regardless of changes in federal law," he will, "ensure that Oregon remains a pro-choice state and that all Oregonians maintain full access to reproductive rights and healthcare. ${ }^{230}$ Though abortion is a politically partisan debate nationally, Oregon shows that within its borders that is not necessarily the case. Locate his campaign website at Knute Buehler, 2017. "Oregon Ambitions and Outcomes:

Healthcare." Knute for Governor. Accessed November 4, 2018.

https://knutebuehler.com/oregon-ambitions-outcomes-health-care/. 


\section{Bibliography}

\section{Primary Documents}

Barnett, Ruth., and Baker, Doug. They Weep on My Doorstep. Beaverton, Or.: Halo Publishers, 1969.

Roberts, Betty., and Wells, Gail. With Grit and by Grace: Breaking Trails in Politics and Law, A memoir. Corvallis, OR: Oregon State University Press, 2008.

Archival Sources

Oregon Historical Society, Davies Family Research Library,1990 Voters' Pamphlet. State of Oregon General Election. Portland, OR.

Oregon Historical Society, Davies Family Research Library, Charles Hinkle Collection. Portland, OR.

Oregon Historical Society, Davies Family Research Library, Politics and Miscellaneous, Gay and Lesbian Periodicals Collection, Portland, OR.

Oregon State Archives, Regular Session Legislative Journals years: 1973-2001. Salem, OR.

Portland State University Special Collections, Ballot Measure Archive Project, Portland, OR

Portland State University. Special Collections. Betty Roberts Papers. Portland, OR.

Portland State University Special Collections: Gretchen Kafoury Papers. Portland, OR.

Newspapers

"Bar, school board group oppose measure to restrict abortion funds," The Oregonian, September 4, 1986.

"Community Events," The Oregonian, September 25, 1986.

\section{Secondary Sources \\ Books}

Dochuk, Darren. From Bible Belt to Sunbelt : Plain-folk Religion, Grassroots Politics, and the Rise of Evangelical Conservatism. New York: W.W. Norton, 2011.

Durham, Martin. The Christian right, the Far Right and the Boundaries of American Conservatism. Manchester: Manchester University Press, 2000.

Epstein, Lee and Walker, Thomas G. Constitutional Law for a Changing America: Rights, Liberties, and Justice. $9^{\text {th }}$ ed. Los Angeles: CQ Press, 2016.

Gordan, Linda. Woman's Body, Woman's Right: Birth Control in America. New York: Penguin Books, 1974.

Helquist, Michael. Marie Equi: Radical Politics and Outlaw Passions. Corvallis: Oregon State University Press, 2015. 
Kerber, Linda K. No Constitutional Right to be Ladies: Women and the Obligations of Citizenship. New York, NY: Hill and Wang, 1998.

Luker, Kristin. Abortion and the Politics of Motherhood. Berkeley: University of California Press, 1984.

Marsden, George M. Fundamentalism and American Culture. New York: Oxford University Press, 2006.

Marsh, Tom. To the Promised Land: A History of Government and Politics in Oregon. Corvallis: Oregon State University Press, 2012.

McGirr, Lisa. Suburban Warriors : The Origins of the New American Right. Princeton, N.J.: Princeton University Press, 2001.

Milligan, Susan. "Oregon Passes Law Protecting Abortion Rights," U.S. and World News, August 15, 2017.

Petchesky, Rosalind Pollack. Abortion and Woman's Choice: The State, Sexuality and Reproductive Freedom, (Chicago, Northwestern University: 1984) 389.

Rae, Nicol C. The Decline and Fall of the Liberal Republicans: From 1952 to the Present. New York: Oxford University Press, 1989.

Reagan, Leslie. When Abortion was a Crime: Women, Medicine, and the Law in the United States, 1867-1973. Berkely: University of California Press, 1997.

Rose, Melody. Safe Legal and Unavailable?: Abortion Politics in the United States. Washington D.C.: CQ Books, 2007.

Solinger, Rickie. The Abortionist: A Woman Against the Law. New York: The Free Press, 1994.

Solinger, Rickie. Pregnancy and Power: A Short History of Reproductive Politics in America. New York: New York University Press, 2005.

Thomas, Sue. How Women Legislate. New York, NY: Oxford University Press, 1994.

Williams, Daniel K. Defenders of the Unborn: The Pro-life Movement before Roe $v$. Wade. New York, NY: Oxford University Press, 2016.

Daniel K. Williams, God's Own Party: The Making of the Christian Right, (Oxford: Oxford University Press, 2011).

Young, Neil J. We Gather Together: The Religious Right and the Problem of Interfaith Politics. New York: Oxford University Press, 2016.

The Abortion Rights Controversy in America: A Legal Reader, Ed: N.E.H. Hull, Williamjames Hoffer, Peter Charles Hoffer. Chapel Hill: University of North Carolina Press, 2004.

Articles

Cheppel, Bill. "Judge Temporarily Blocks Iowa's 'Fetal Heartbeat' Abortion Law," $N P R$, June 1, 2018.

Elder, Laurel. "Contrasting Party Dynamics: A Three Decade Analysis of the Representation of Democratic Versus Republican Women State Legislators," The Social Science Journal, 51, (2014): 377-385.

Helquist, Michael. " 'Criminal Operations': The First Fifty Years of Abortion Trials in Portland, Oregon," Oregon Historical Society, 116, no.1 (Spring 2015). 
Mohr, James, C. “Abortion In America," in Women's America: Refocusing the Past, $7^{\text {th }}$ edition, Ed. Linda K. Kerber, Jane Sherron De Hart, Cornelia Hughes Dayton, (Oxford University Press: 2011).

Milligan, Susan. "Oregon Passes Law Protecting Abortion Rights," U.S. and World News, August 15, 2017.

Rose, Melody and Watson, Tara. "She Flies With Her Own Wings: Women in the 1973 Oregon Legislative Session," Oregon Historical Society, 111, no.1, (Spring 2010): 38.

Tamney, Joseph B, Johnson, Stephen D, and Burton, Ronald. "The Abortion Controversy: Conflicting Beliefs and Values in American Society," Journal for the Scientific Study of Religion, 31, no.1, (March 1992): 32-46.

Torres, Aida; Donovan, Patricia; Dittes, Nancy; Darroch, Jacqueline Forrest. "Public Benefits and Costs of Government Funding for Abortion," Family Planning Perspectives, 18, no.3 (1986).

Zumbrunnen, John, and Amy Gangl. "Conflict, Fusion, or Coexistence? The Complexity of Contemporary American Conservatism." Political Behavior 30, no. 2 (2008): 199-221.

Master's Theses

Adams, Sadie Anne. "We Were Privileged in Oregon: Jessie Laird Brodie and Reproductive Politics, Locally and Transnationally, 1915-1975." Master's Thesis: Portland State University, 2012.

Cookler, Beth. "The Impact of the Tax Revolt and School Reform on Oregon Schools during the 1990's." master's thesis: Portland State University, 2014.

Young, Patricia Jean. “Measure 9: Oregon's 1992 Anti-Gay Initiative. master's thesis: Portland State University, 1997. 